\title{
Contradictions and continuities: a historical context to Euro-American settlement era fires of the Lake States, USA
}

\author{
Jed Meunier ${ }^{*}$ (1)
}

\begin{abstract}
Background: The Lake States experienced unprecedented land use changes during Euro-American settlement including large, destructive fires. Forest changes were radical in this region and largely attributed to anomalous settlement era fires in slash (cumulation of tops and branches) following cutover logging. In this study, I place settlement era fires in a historical context by examining fire scar data in comparison to historical accounts and investigate firevegetation-climate relationships within a 400-year context.

Results: Settlement era fires (1851-1947) were less frequent than pre-settlement fires (1548-1850) with little evidence that slash impacted fire frequency or occurrence at site or ecoregion scales. Only one out of 25 sites had more frequent settlement era fires, and that site was a pine forest that had never been harvested. Settlement era fires were similar across disparate ecoregions and forest types including areas with very different land use history. Settlement fires tended to burn during significantly dry periods, the same conditions driving large fires for the past 400 years. The burned area in the October 8, 1871, Peshtigo Fire was comprised of mesic forests where fuels were always abundant and high-severity fires would be expected under the drought conditions in 1871. Furthermore, slash would not have been a major contributor to fire behavior or effects in the Peshtigo Fire when logging was still limited to relatively accessible pine forests.

Conclusions: Historical written accounts of fires and settlement era survey records provide a reference point for landscape changes but lack temporal depth to understand forest dynamics. Tree-ring analyses provide a longer (ca. 400 year) context and more mechanistic understanding of landscape dynamics. While settlement land use changes of Lake States forests were pervasive, fires were not the ultimate degrading factor, but rather likely one of the few natural processes still at work.
\end{abstract}

Keywords: Cutover, Dendrochronology, Fire history, Michigan, Peshtigo fire, Pinus resinosa, Red pine, Slash, Wildfire, Wisconsin

*Correspondence: jed.meunier@wisconsin.gov

Wisconsin Department of Natural Resources, Division of Forestry, 2801

Progress Road, Madison, WI 53716, USA 


\section{Resumen}

Antecedentes: Los estados de la Región de los Lagos en EEUU experimentaron cambios sin precedentes en el uso de la tierra, incluyendo incendios grandes y destructivos. Los cambios radicales en los bosques en esta región fueron atribuidos mayoritariamente a incendios anómalos durante la colonización, mediante la quema de pilas (acumulación de ramas y parte superior del dosel de árboles), luego de cortas de aprovechamiento forestal. En este estudio, enmarco los incendios en la era de la colonización en un contexto histórico mediante el examen de datos de cicatrices de fuego en comparación con los datos históricos, e investigo la relación fuego-vegetación-clima dentro de un contexto de 400 años.

Resultados: Los incendios de la era de la colonización (1851-1947) fueron menos frecuentes que los fuegos previos a la colonización (1548-1850), con poca evidencia de que las quemas en pilas impactaran en la frecuencia u ocurrencia a nivel de sitio o a escala regional. Solo uno de los 25 sitios examinados tuvo mayores frecuencias de incendios en la era de la colonización, siendo ese sitio un bosque de pinos que nunca había sido talado/cosechado. Los incendios de la era de la colonización fueron similares a lo largo de diferentes eco-regiones y tipos de bosques, incluyendo áreas con muy diferente historia de uso. Los incendios durante la colonización tendieron a desarrollarse durante períodos significativamente secos, las mismas condiciones que llevaron a grandes incendios en los últimos 400 años. El área quemada el 8 de octubre de 1871 en el incendio de Peshtigo, comprendió a bosques mésicos donde el combustible vegetal fue siempre abundante e incendios de alta severidad eran predecibles debido a las condiciones de sequía del año 1871. Además, las quemas en pilas no habrían contribuido mayormente al comportamiento del fuego o sus efectos, dado que la tala estaba todavía limitada a bosques de pino más accesibles.

Conclusiones: los escritos históricos y los relevamientos de registros de fuegos en la era de la colonización, proveen de un punto de referencia para detectar los cambios en el paisaje, pero carecen de profundidad temporal como para entender la dinámica de los bosques. Los análisis de anillos de crecimiento proveen de contextos más amplios (ca 400 años) y un entendimiento más mecanístico sobre la dinámica del paisaje. Mientras que los cambios en el uso de la tierra durante la colonización en los Estados de los Lagos fueron persistentes, los incendios no fueron el factor último de degradación, sino muy probablemente unos de los pocos procesos naturales que todavía perduran.

\section{Introduction}

As climate and fire regimes change, new understanding is needed of the inherent resilience of ecosystems and of the implications for human communities and ecosystem services (Hessburg et al. 2019). Following a period of rapid and intense land-use during Euro-American settlement (settlement) and associated ecosystem changes, forests of the Lake States are now more homogeneous, with less species diversity (Schulte et al. 2007) and less spatial and structural complexity (Meunier et al. 2019a) and are less coupled to local climate controls (Thompson et al. 2013), all of which lead to a loss of resilience in forest ecosystems (Drever et al. 2006). It remains unclear what the relative contributions of logging, slash fires, or subsequent fire suppression were to changes in Lake States forests (White and Mladenoff 1994; Rhemtulla et al. 2009). It was assumed that settlement era fires were anomalous, with more frequent and severe fires resulting from cutover slash (White and Host 2008). Early laws were passed to require disposal of slash (Wright Jr. and Heinselman, 2014) and the prevention of wildfires at all costs formed the basis of forest conservation in the Lake States. In the modern era, human-induced disequilibrium (e.g., fire exclusion via landscape fragmentation, grazing, and fire suppression) has weakened the relationships among fire, vegetation, and climate (Marlon et al. 2012; Higuera et al. 2015). This limits our understanding of these interacting factors, thus necessitating longerterm historical perspectives (Parks et al. 2017). Despite these limitations, much of our understanding of fire history comes from recent decades and periods when both climate and human activities have undergone rapid and unique transformations (Marlon et al. 2012; Meunier and Shea 2020).

Perhaps nowhere is the rapid and unique transformation of land illustrated better than the $>20$ million hectare "Great Cutover" of the Lake States forests. While some logging preceded legal title, this era began primarily after the original General Land Office public land surveys (Stewart 1935) were carried out (Michigan: 1816-1856, Wisconsin: 1833-1866, Minnesota: 18481907) and was largely concluded by 1920 after the Lake States were denuded (Stearns 1997; Kates 2001). While the Cutover is sometimes reduced to a relatively discrete, singular event, it occurred in multiple phases over a period of 60 years. The initial phase of cutting, "river lumbering," was confined to pine forests near rivers and streams as it was unprofitable to haul logs any distance 
to water (Whitney 1987). It was not until the 1880 s that railroad expansion in northern forests opened new areas for logging including more isolated softwood stands and especially hardwoods like maple (Acer $\mathrm{spp}$.), which could not be floated down rivers (Roth 1898; Larson and Larson 2016). After 1880, both the scale and intensity of logging expanded dramatically, ushering in one of the most intense periods of logging the temperate world has ever seen (Marquis 1975; Whitney 1990). The peak harvest of pine was ca. 1890 (in Michigan and Wisconsin, 1900 in Minnesota) and by 1920 harvest of hardwoods exceeded pine (Stearns 1997). Weaver and Clements (1929) stated that the pine-hemlock forest of the Lakes States had been reduced to such small fragments that there were doubts about its former existence (Whitney 1987).

While cutover logging was globally unprecedented in its speed and intensity (Whitney 1987; Williams 1989; Schulte et al. 2007), it was the repeated and often intense slash fires (Zon and Cunningham 1931; Schulte et al. 2007) that followed which "all the authorities agreed" were the primary source of land degradation rather than logging itself (Roth 1905; Curtis 1959; Whitney 1987). In fact, fires at the time were used to justify logging by timber barons who were depicted not as wasteful capitalists, but rather saving forests from waste by fires (Stimson 1910). The sentiment of "more good pine timber was burned than ever reached the sawmills" was handed down as common knowledge among lumbermen at the time (Zon and Cunningham 1931; Dickmann and Leefers, 2003) and subsequently even by researchers examining the profligate logging practices of the Cutover (Fries 1951; Whitney 1987). Fires fed by pine slash were often viewed as the ultimate degradation of Lake States forests leading to long-term structural and compositional changes and loss (Bormann and Likens 1979). Fires were of course associated with land use changes including exorbitantly wasteful logging, but were also often followed with clearing stumps for farmers (19 million pounds of explosives were used by the University of Wisconsin College of Agriculture alone; Gough 1997), nearly universally failed attempts at farming (Whitney 1987), and subsequent fire suppression.

Certainly, large and destructive fires in this period were common, including the deadliest wildfire in American history-the October 8, 1871, Peshtigo Fire in Wisconsin (Gess and Lutz 2003). Named fire events are mostly useful to managers responding to particular conflagrations whereas ecologists tend to describe large fire years. The fires of October 8, 1871, for example, famously destroyed $9 \mathrm{~km}^{2}$ of the city of Chicago and killed several hundred people. At the same time, they burned $>10,000 \mathrm{~km}^{2}$ and multiple cities (e.g., Holland, Lansing, Port Huron, Manistee) in lower Michigan (Dickmann and Leefers 2003).
These fires are sometimes collectively called "the great Midwest fires of 1871." In Minnesota, the "Great Fires" denote the especially destructive fire years of 1894, 1908, 1910, and 1918 (Haines and Sando 1969; Johnson 2020). During these destructive fire years, tens of thousands of hectares also burned elsewhere in the Lake States. In Wisconsin, for example, 1894 is the year of the "Phillips Fire" which burned over eight counties in late July, destroying the town of Phillips and killing several hundred people. What these settlement fires have in common is that they were, and continue to be, considered anomalies. Interestingly, 150 years after the fact, we still not only attribute the 1871 fires to extraordinary and anomalous conditions but also take solace in the belief that those conditions will not repeat themselves (Frelich 2002; National Oceanic and Atmospheric Administration, National Weather Service, 2021). Yet, in the Lake States region, we have only a nascent understanding of fire regimes in relation to vegetation and climate (Meunier et al. 2019a). Thus far, there has been little effort to view settlement era fires in a greater historical and ecological context.

The first systematic attempt to evaluate the problem of slash as a fire hazard was led by the architect of research in the U.S. Forest Service, Raphael Zon. Zon and Cunningham (1931) found that settlement era fires were a result of weather conditions, not slash, and that any impact on fire intensity/severity would have been both localized, since slash covered a small proportion of cutover areas, and short-lived (Cheyney 1939). Yet, slash remained a primary culprit for uncontrolled wildfires, which posed a "serious problem to those concerned with fire control" (Williams 1955), perpetuating the notion that settlement era fires were unprecedented in intensity and frequency (Dickmann and Cleland, 2002, White and Host 2008) and driven primarily by slash (Wells 1968; Brose et al. 2001; Frelich 2002). It was commonly held, for example, that fire seldom swept into "virgin stands" for more than 10 rods in the absence of logging slash (Lorimer 1980).

Although fuel accumulation was blamed for one of the largest and most destructive fires in Michigan in 1881, the same ground had burned just one decade prior in 1871 . At the time, the severity of the 1881 fires was blamed in part by dead timber from the 1871 fire and slash building up for decades (Rummel 2003). However, slash buildup over long periods is in direct contradiction to findings by Zon and Cunningham (1931). In semiarid regions, the importance of fires in constraining fire growth and severity of subsequent fires is unequivocal (Stephens et al. 2012). It follows that repeated fires in dry pine forests in Michigan have been shown to reduce woody debris and the duff layer, generally resulting in 
less intense subsequent fires (Drobyshev et al. 2008). Yet, the relative importance of fuels (reduction via burning or addition via slash) to fire behavior and effects in more mesic temperate forests, which predominated in the region of the 1881 fires, are less clear (Comer et al. 1995; Steel et al. 2015).

As the environmental historian William Cronon (1983) stated, "an ecological history begins by assuming a dynamic and changing relationship between environment and culture, one as apt to produce contradictions as continuities." In this study, I attempted to ascertain the contradictions and continuities of our recent fire history for the Lake States, a period of profound changes and importance that we are only beginning to critically evaluate after more than a century. My objective was to evaluate fires of the settlement era in a context of a longer fire chronology and in relation to vegetation and climate using fine scale dendrochronology reconstructions of fire history. Specifically, I evaluated fire frequency and the similarity of fire events between pre-settlement (prior to 1851), and settlement (1851- ca. 1930) periods. I further assessed fire vegetation characteristics for the 1871 Peshtigo Fire in Wisconsin, USA.

\section{Methods}

Study area

This study was conducted across Wisconsin (WI) and the Upper Peninsula (UP) of Michigan, USA, spanning a 4-degree latitudinal $\left(43^{\circ}\right.$ to $\left.47^{\circ} \mathrm{N}\right)$ and 8-degree longitudinal $\left(-84^{\circ}\right.$ to $\left.-92^{\circ} \mathrm{W}\right)$ gradient and included eight ecoregions (Fig. 1; Omernik 1987; Omernick and Griffith 2014). Ecoregions are large ecological landscapes with specific biophysical characteristics defined in part by successive glaciation events that have created diverse forest types across the Lake States (Wisconsin Department of Natural Resources, 2015; Meunier et al. 2019b). Within these ecoregions, fire history data from remnant and living fire scarred trees were collected in 25 study sites, each with a component of pine (Pinus spp.), but which were otherwise disparate, allowing comparisons of disturbance history among broad geographical regions with varying physiography and forest types. Ecoregions (east to

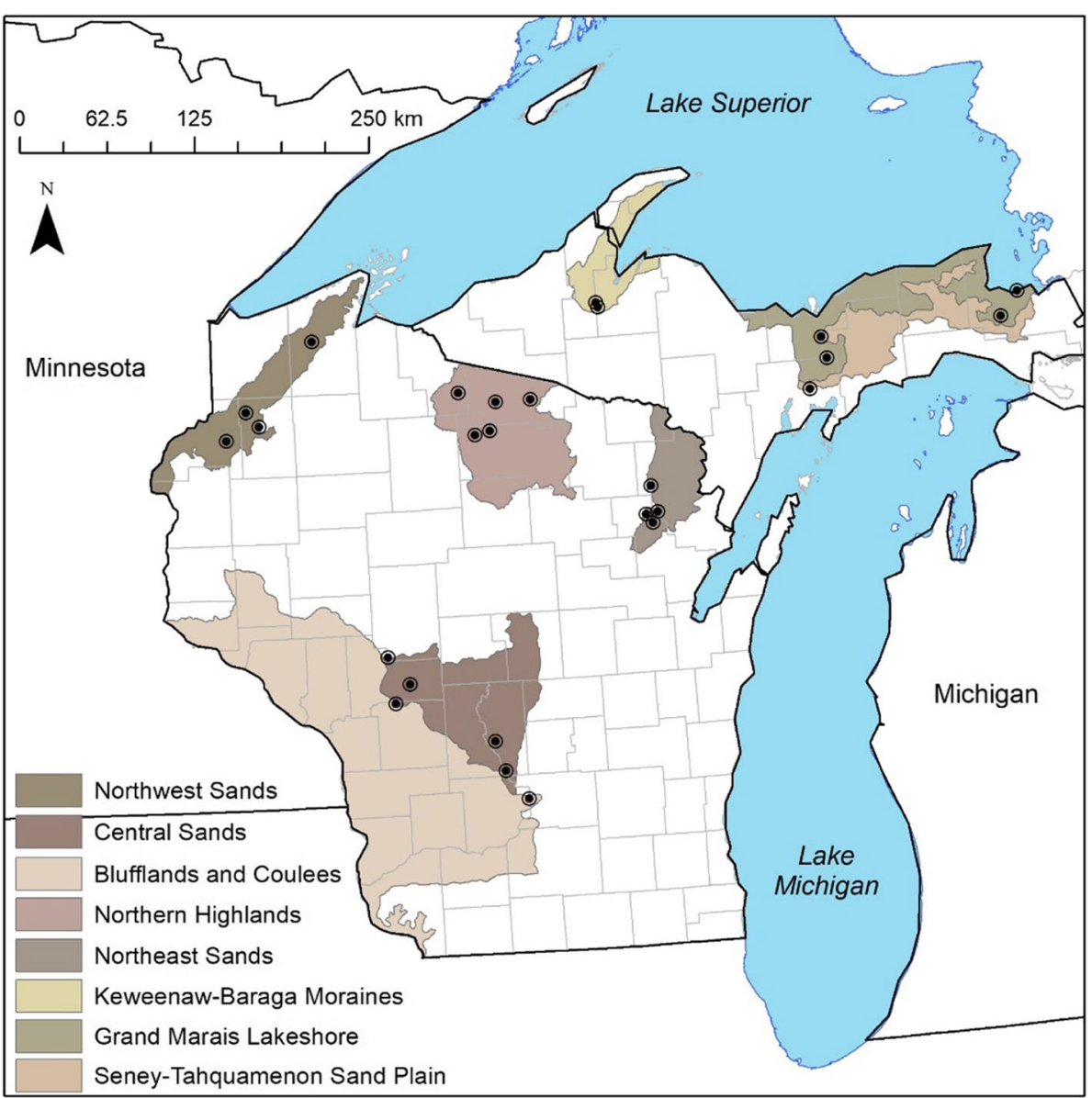

Fig. 1 Study sites ( $n=25$ ) among eight ecoregions in Wisconsin and the Upper Peninsula of Michigan in the Lake States, USA 
west) were as follows (Wisconsin Department of Natural Resources, 2015; Meunier et al. 2019b):

(1) Northwest Sands (NWS), WI $\left(4628 \mathrm{~km}^{2}\right)$-a deep, well-drained sand outwash complex with relatively flat to rolling topography, with lakes limited to the southern portion. This ecoregion had a high proportion of pine ( $>93 \%$ of settlement survey "witness trees"; Meunier and Shea 2020) and pine barrens (northern savannas on infertile soils). Several notable settlement era fires are documented in historical records in this landscape, including a fire in 1854 (Amery, WI to Iron River, WI), the 1894 Phillips Fire (eight counties surrounding Phillips including NWS, WI; Brown 2009), and an 1898 fire (Barron and Polk counties, Wisconsin Historical Society, 2021).

(2) Central Sands (CS), WI $\left(7068 \mathrm{~km}^{2}\right)$ - a glacial lakebed of well-drained outwash sands intermixed with wetlands, but with few natural lakes or rivers and very little topography. Currently, this landscape consists of a high proportion of dry pine-oak barrens and forest. Historically, the region had higher proportions of pine (62\% of original land survey witness trees; Mladenoff 2009, Meunier and Shea, 2020), including red and white pines (P. resinosa, P. strobus) in the northwest (Bruce Mound, Wildcat Ridge, Stoney Bluff sites) and jack pine (P. banksiana) in the central portions (Quincy Bluff site) of the ecoregion. A particularly destructive settlement era fire in this landscape was "The Great Marshfield Fire" in June 1887 (Wood and Marathon Counties, WI).

(3) Blufflands and Coulees (B\&C), WI $\left(23,004 \mathrm{~km}^{2}\right)-$ an unglaciated region of silt and loam soils with few natural lakes and wetlands, but complex ridge and valley topography. Within the Bluff and Coulee region, I collected fire scar samples within a red pine relict (Pine Bluff) occurring on steep bluffs with an exposed sandstone outcrop in an otherwise hardwood-dominated landscape that was primarily white oak (Quercus alba) woodland in pre-settlement times.

(4) Northern Highlands (NH), WI $\left(6821 \mathrm{~km}^{2}\right)$-a region with rolling topography with pitted-gravelly sands and abundant natural lakes, rivers, and streams. While sandy soils predominate, the soils tend to be more productive in this ecoregion and support dry-mesic mixed conifer forests which comprised ca. $56 \%$ of witness trees in the original survey notes. Historically, this landscape was Wisconsin's greatest pinery, but also contained abundant eastern hemlock (Tsuga canadensis)-hard- woods, as well as aspen-birch (Populous-Betula). Notable settlement era fires include a large fire in 1904, again in 1907-1908, and 1910 (WI Historical Society Wisconsin Historical Society, 2021).

(5) Northeast Sands (NES), WI $\left(2865 \mathrm{~km}^{2}\right)$-deep, well-drained outwash sands with level to rolling topography and scattered, small lakes. This landscape had a high proportion of pine forests $(62 \%$ of settlement survey witness trees). Notable settlement era fires included one in 1900 (Chequamegon Bay and Menominee River). Two sampling sites in this ecoregion (Wolf Lane and Camp Bird) were old growth pine stands that were never harvested.

(6) The Keweenaw-Baraga Moraines (KBM), UP $\left(2409 \mathrm{~km}^{2}\right)$ - primarily northern hardwood forest including sugar and red maple (Acer saccharum and $A$. rubrum), yellow birch (Betula alleghaniensis), aspen (Populus), red and white pine, and eastern hemlock. This ecoregion, and sites within it (Bears Den, Pine Bluff Trail), is characterized by broad ridges and steep morainal slopes with welldrained sandy soils. Pine is a scattered but minor component of forests within this ecoregion. A notable fire in this ecoregion was in 1896 which burned $>900 \mathrm{~km}^{2}$ leveling the town of Ontonagon to the west (Dickmann and Leefers 2003).

(7) The Seney-Tahquamenon Sand Plain (SSP), UP $\left(3765 \mathrm{~km}^{2}\right)$ - primarily mixed conifer swamp, mus$\mathrm{keg} / \mathrm{bog}$, and patterned peatlands dominated by tamarack (Larix laricina) and black spruce (Picea mariana) on poorly-drained sand lake plains with mixed pine forests (red, jack, and white pines) on sandy ridges and dunes. Ramsey Lake typified this landscape and was a 900-ha patterned fen peatland.

(8) The Grand Marais Lakeshore (GML), UP $\left(5284 \mathrm{~km}^{2}\right)$-red and jack pine ridges and dunes along Lake Superior with interior uplands containing scattered northern hardwoods and eastern hemlock-white pine forests. Peatlands occur in poorly drained lacustrine deposits and in glacial kettle depressions. Sites in this ecoregion ranged from >1200 ha peatland (Betchler Lake), pockets of pine along Lake Superior (Bay View), to more extensive interior forest (Corner Lake, Hwy 13).

\section{Data collection and analysis}

Within natural origin red pine-dominated stands, I collected sections from remnant stumps and nondestructively collected partial sections from fire-scarred dead and living trees at $10 \mathrm{~cm}$ height (Fritts and Swetnam 1989). Stands were either old-growth or had been harvested in the cutover period (ca. 1860-1920) but had 
minimal recent disturbance (e.g., post cutover logging) and contained pre-settlement era stumps. Multiple stands comprised sites which ranged in size from small pine stands within hardwood forests to more extensive pine forests for which I made an effort to sample comparable areas $(0.12-2.41 \mathrm{ha}, \mu=0.76 \mathrm{ha})$. Two sites were comprised by unharvested old growth whereas most sites were harvested at the time of cutover but subsequently left relatively undisturbed. Samples were collected from both randomly placed plots used in separate analyses of age structure (e.g., Meunier et al., 2019a, b) as well as opportunistically (Meunier et al. 2019b; Sutheimer et al. 2021). Whether or not fires recorded at study locations were the same as particular fires recorded in historical written accounts cannot be precisely known, but I sought to investigate their correspondence as well as their relative importance described further below.

In the laboratory, I sanded samples until the cellular structure of xylem was clearly visible with magnification (Grissino-Mayer and Swetnam 2000). I used a dissecting microscope to crossdate tree-rings and assigned exact calendar dates to all fire-scars using standard dendrochronology techniques (Speer 2010). I compiled and analyzed fire-scar chronologies for each site using Fire History Analysis and Exploration System software version 2.0 (FHAES, Brewer et al. 2019). Most trees, once large enough to be protected by thick bark, are not injured by low-intensity fires; however, once injured, trees are more susceptible to repeated injury in subsequent fires and considered "recording trees" (Swetnam and Baisan 1996). It follows that fire scars are evidence of trees that were scarred but survived low- to moderate-severity fires. I analyzed mean fire return intervals (MFRI- the average number of years between fires) within sites in which fires occurred on $\geq 10 \%$ of recorder trees by settlement and pre-settlement periods framed broadly by settlement patterns using 1850 as the cutoff (pre-settlement $\leq 1850$ ). For post-settlement chronologies, I included the years up to the time that a major disruption of fire events was apparent excluding unusually long MFRI's associated with fire exclusion. Filtering, based on scarring percentage, provides a relative index of fire size (Farris et al. 2010). A 10\% filter, for example, will only consider fire years recorded on $\geq 10 \%$ of recorder trees, thus eliminating fires that may have burned only one or few trees in a single lightning strike or localized incident (Meunier et al. 2014). I also calculated Weibull median probability interval (WMPI) which is a lessbiased estimator of central tendency with skewed data (Grissino-Mayer 1999), but MFRI are more commonly reported (e.g., LANDFIRE 2016).

To test for differences in historical fire frequency between settlement and pre-settlement periods, I compared MFRI for fires recorded on $\geq 10 \%$ of recorder trees between time periods (SigmaPlot Version 12.0, 2010). I used two-tailed Student's $t$-test to compare MRFI when data were normally distributed with equal variance and nonparametric Mann-Whitney rank sum tests to compare periods when data were not normally distributed. I compared fire frequencies by site $(n=25)$ and for sites pooled by ecoregion $(n=8)$ and used MFRI distribution to compare median values and data spread for pre-settlement and settlement periods.

Composite fire intervals (e.g., fires on $\geq 10 \%$ recorder trees) are influenced by the number of fire-scarred trees sampled; the more trees sampled the lower the likelihood of missing a fire (Lafon et al. 2017). MFRIs are also influenced by the level of filtering; higher levels of filtering usually result in fewer, larger fire years and longer MFRI. Therefore, I also evaluated temporal variations in fire with a decadal fire index (DFI) which does not depend on compositing and accounts for sample depth (Hoss et al. 2008). DFI is calculated by first summing the number of fires recorded during each decade and dividing by the number of recording trees that are represented during the decade (Lafon et al. 2017). Dividing by the number of recording trees standardizes fire sums and permits comparison of decades with different sample sizes (Lafon et al. 2017). I regressed DFI against time for the entire pre-exclusion period (both settlement and presettlement eras) to test for trends (i.e., positive or negative slope) over time. The Cutover generally followed an east-to-west progression (Maine to Michigan and Wisconsin, then Minnesota) with geographic factors playing an important role in the settlement era lumber industry (Stearns 1997). In addition to site trends, I evaluated regionally composited fire occurrence changes to try and detect these broader spatial scale fire patterns.

There is no robust way to compare historical written accounts of settlement era fires to tree-ring based fire scar records. However, to try to ascertain general agreement between historical accounts and fire-scar data, I calculated the proportion of regions that recorded well-known large fire events. This allowed me to evaluate whether particularly large settlement era fires, as depicted from historical written accounts, were also more widespread (higher proportion of ecoregions recording the same fire year) based on fire scar data (Meunier and Shea 2020). I also composited fire history among all sites (659 fire-scar samples) into a single fire chronology and used a more restrictive filter-fires recorded on $\geq 15 \%$ of all recorder trees, with a minimum sample size of 10 recording treesto compare how the largest fire years, reconstructed with fire-scar samples, compared to known settlement era fires. Setting a minimum sample size of 10 recorder trees helps to reduce the influence of early fire years that 
scar a high proportion of trees due to small sample sizes. I compared the largest fire years (recorded on $\geq 15 \%$ of recorder trees for all samples combined) across both pre-settlement and settlement periods with this composited fire history. I used superposed epoch analysis (SEA) to understand climate drivers (average Palmer Drought Severity Index, PDSI, of four grid points across the region; Cook et al. 2007) for both widespread fire years with $\geq$ $15 \%$ rate of scarring across all sites/samples and for notable settlement era fires via historical accounts.

Generally, fire perimeters for settlement era fires are anecdotal and/or lack detailed descriptions of spatial extent and patterns making fire-vegetation characteristics difficult to ascertain. The 1871 Peshtigo Fire is an exception having reasonably well-documented fire perimeter maps (Fig. 2). To evaluate fire-vegetation characteristics in relation to land use changes (e.g., slash), I overlaid the approximate boundaries for the $4856 \mathrm{~km}^{2}$ Wisconsin portion of the October 1871 Peshtigo fire and extracted all settlement era General Land Office Public Land Survey (GLO) witness tree records that intersected the Peshtigo fire boundary (Sickley et al. 2001). The survey, which was designed to form the basis of property boundaries and land records during the settlement era, included notes on the species, diameter, and location relative to section corners of two to four witness trees (Stewart 1935). I overlayed the Peshtigo fire footprint on a raster map of GLO witness trees and extracted all witness trees within the boundary of the Peshtigo Fire to evaluate forest composition of that landscape at the time of settlement using ArcMap 10.3 (Environmental Systems Research Institute (ESRI), 2014).

\section{Results}

This study included 659 crossdated fire-scarred tree samples collected among the 25 sites spanning the period from 1548 (the first fire included in analyses) to 1947 when effective fire exclusion was apparent among all sites. The temporal extent of tree-ring records varied among sites but, collectively, I identified 3229 fires from 1548 to 1947 . Despite very different landscape contexts and forest composition among ecoregions and sites, prior to the mid-1900s, fires were historically frequent in all locations, with MFRI ranging from 3 to 15 years $(\mu=8)$ for fires recorded on $\geq 10 \%$ of recorder trees (Table 1 ). When considering fires that were recorded on $\geq 25 \%$ of recorder trees (larger fire years), fire frequency decreased slightly but were still frequent (MFRI $=5-34$ years, $\mu=12$ ). In general, fires were most frequent in the Central Sands, Blufflands and Coulees, and Northwest Sands ecological landscapes $(M F R I=4)$ and longest in the Keweenaw-Baraga Moraines $(\mathrm{MFRI}=12)$ and SeneyTahquamenon Sand Plain (MFRI $=11)$.

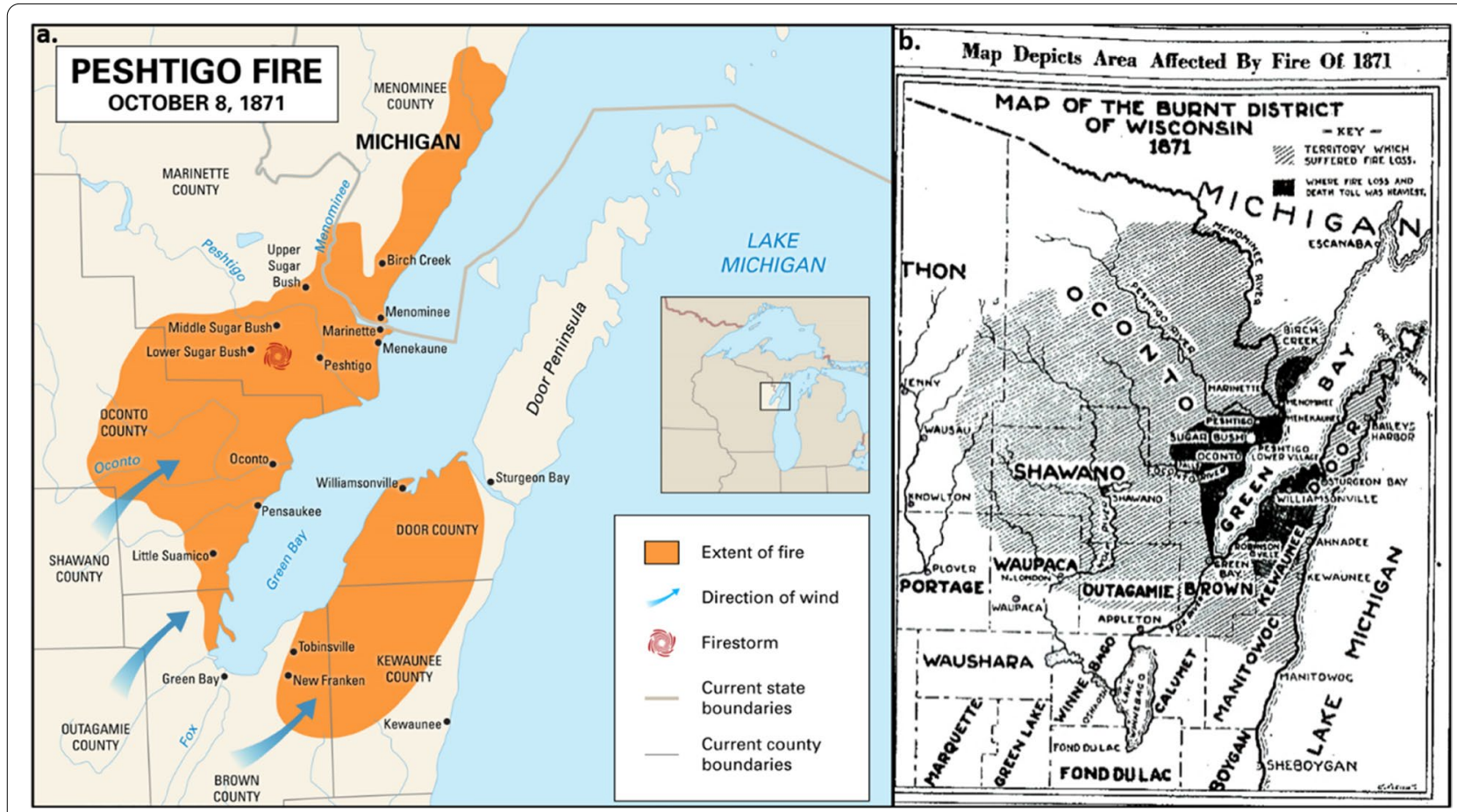

Fig. 2 Maps depicting burned areas in the a October 8, 1871 Peshtigo Fire, Wisconsin where fire loss and death toll was greatest (by courtesy of Encyclopedia Britannica, Inc., copyright 2020; used with permission) and b northeastern Wisconsin region fire maps in 1871 (originally published The Sheboygan Press, October 8, 1929). 
Table 1 Fire interval metrics (years) for fires recorded on $\geq 10 \%$ of recording trees at each site $(n=25)$ until the time of disruption of fire events were apparent

\begin{tabular}{|c|c|c|c|c|c|c|c|c|}
\hline Site & Region & Years & No. samples & No. fires & No. Int. & MFRI & WMPI & $\begin{array}{l}\text { Min- } \\
\text { max } \\
\text { interval }\end{array}$ \\
\hline Totogatic River & NWS & 1710-1946 & 27 & 206 & 43 & 6 & 5 & $1-25$ \\
\hline Inch Lake & NWS & 1699-1926 & 34 & 127 & 37 & 6 & 6 & $1-16$ \\
\hline Lampson Pines & NWS & 1747-1947 & 14 & 96 & 36 & 6 & 4 & $1-25$ \\
\hline Sand Lake & NWS & $1737-1884$ & 29 & 270 & 38 & 4 & 4 & $1-10$ \\
\hline Bruce Mound & CS & 1707-1935 & 59 & 219 & 20 & 11 & 10 & $1-31$ \\
\hline Wildcat Ridge & CS & $1771-1857$ & 49 & 216 & 13 & 7 & 6 & $1-16$ \\
\hline Stoney Bluff & CS & 1704-1934 & 20 & 118 & 25 & 9 & 7 & $1-47$ \\
\hline Quincy Bluff & CS & 1694-1930 & 23 & 180 & 71 & 3 & 3 & $1-10$ \\
\hline Wisconsin Dells & CS & $1681-1924$ & 28 & 225 & 58 & 4 & 4 & $1-11$ \\
\hline Pine Bluff & $B \& C$ & 1684-1895 & 17 & 168 & 51 & 4 & 4 & $1-17$ \\
\hline Cathedral Point & $\mathrm{NH}$ & 1797-1908 & 24 & 60 & 4 & 6 & 4 & $1-14$ \\
\hline Frog Lake & $\mathrm{NH}$ & 1833-1941 & 14 & 53 & 14 & 8 & 7 & $1-15$ \\
\hline Squirrel River & $\mathrm{NH}$ & 1744-1910 & 16 & 48 & 19 & 9 & 7 & $1-31$ \\
\hline Finnerud Pines & $\mathrm{NH}$ & 1736-1907 & 39 & 147 & 19 & 9 & 8 & $1-18$ \\
\hline Buckatabon & $\mathrm{NH}$ & 1697-1910 & 15 & 45 & 26 & 8 & 6 & $1-38$ \\
\hline Camp Bird & NES & 1764-1925 & 17 & 141 & 28 & 6 & 5 & $1-14$ \\
\hline Wolf Lane & NES & 1818-1926 & 16 & 109 & 16 & 7 & 6 & $3-17$ \\
\hline Tar Dam Road & NES & $1714-1855$ & 25 & 151 & 13 & 11 & 10 & $3-31$ \\
\hline Bears Den & KBM & 1721-1909 & 13 & 40 & 13 & 15 & 9 & $1-55$ \\
\hline Pine Bluff Trail & KBM & 1659-1927 & 25 & 82 & 26 & 10 & 8 & $1-34$ \\
\hline Betchler Lake & GML & 1548-1920 & 62 & 190 & 43 & 9 & 7 & $1-32$ \\
\hline Bay View & GML & 1777-1932 & 15 & 67 & 19 & 8 & 7 & $2-25$ \\
\hline Hwy 13 & GML & 1574-1910 & 17 & 75 & 29 & 12 & 7 & $1-70$ \\
\hline Corner Lake & GML & 1699-1946 & 20 & 63 & 16 & 15 & 9 & $1-84$ \\
\hline Ramsey Lake & SSP & 1637-1932 & 41 & 133 & 27 & 11 & 9 & $1-35$ \\
\hline
\end{tabular}

I report both mean fire return interval (MFRI) and Weibull Median Probability Interval (WMPI) which is where half of the probability distribution is below and half above the value

Among the 25 different sites, fire frequency was significantly different between pre-settlement and settlement periods at only three sites (Sand Lake, Pine Bluff, and Camp Bird; Table 2). Two sites (Sand Lake and Pine Bluff) had significantly shorter MFRI $(P<0.001, P=0.008$ respectively) in the pre-settlement period and one site (Camp Bird) had significantly shorter return intervals $(P=0.046)$ in the settlement $(\mathrm{MFRI}=4)$ versus pre-settlement period (MFRI $=8)$. Results were similar by ecoregion. The Northeast Sands was the only region which had more frequent fire in the settlement period (MFRI presettlement $=8$, settlement $=4 ; P<0.001$ ). The Blufflands and Coulees ecoregion (Pine Bluff) had more frequent fire in the pre-settlement $(M F R I=4)$ than in settlement $(M F R I=9)$. There were no statistical differences in fire frequency between periods in the other six ecoregions, though intervals were longer during settlement (Fig. 3).

When evaluating trends in fire frequency with decadal fire index (DFI), I found no sites that illustrated a significantly positive slope over time. In contrast, six sites had significantly negative slopes, illustrating reduced fire frequency in the settlement period (Table 3). Most sites had no significant changes over time. Similar trends were evident when evaluating DFI by ecoregion. Only the Northwest Sands ecoregion had a positive slope (Fig. 4) but lacked significant differences in DFI over time. Two ecoregions had significantly negative slopes, Bluff and Coulees $(P<0.001)$ and Central Sands $(P<0.001)$, but the Bluff and Coulees ecoregion only had one site (Pine Bluff) and therefore would not be expected to change from site level analyses. In general, there was greater evidence for reduced fire frequency in the settlement period, as compared to pre-settlement, at both site (Table 3 ) and ecoregion (Fig. 4) scales.

During settlement, an estimated $2000 \mathrm{~km}^{2}$ (half million acres) per year burned (Mitchell and LeMay 1952), making it difficult to define significant settlement fire years. I did not compile an extensive bibliography of written 
Table 2 Fire history summaries and tests of difference between Pre-Euro-American (pre-settlement, $\leq$ 1850) and Euro-American settlement (settlement) eras

\begin{tabular}{|c|c|c|c|c|c|c|c|}
\hline & \multicolumn{3}{|c|}{ Pre-settlement } & \multicolumn{3}{|l|}{ Settlement } & \multirow[b]{2}{*}{$P$-value } \\
\hline & Years & MFRI 10\% (\# Int.) & Min-max & Years & MFRI 10\% (\# Int.) & Min-max & \\
\hline \multicolumn{8}{|l|}{ Northwest Sands } \\
\hline Totogatic River & $1710-1840$ & $5(26)$ & $1-14$ & 1854-1946 & $6(16)$ & $1-25$ & 0.648 \\
\hline Inch Lake & 1699-1847 & $8(21)$ & $1-31$ & 1853-1926 & $5(15)$ & $2-14$ & $0.092^{*}$ \\
\hline Lampson Pines & $1747-1846$ & $6(17)$ & $1-25$ & 1851-1947 & $6(18)$ & $1-18$ & 0.548 \\
\hline Sand Lake & $1737-1849$ & $3(32)$ & $1-7$ & $1852-1884$ & $6(5)$ & $3-10$ & $<0.001^{*}$ \\
\hline \multicolumn{8}{|l|}{ Central Sands } \\
\hline Bruce Mound & $1707-1847$ & $11(13)$ & $1-31$ & 1850-1934 & $11(7)$ & $4-18$ & $0.738^{*}$ \\
\hline Wildcat Ridge & $1771-1841$ & $6(12)$ & $1-11$ & $1851-1857$ & x & x & x \\
\hline Stoney Bluff & $1704-1847$ & $9(16)$ & $1-18$ & 1851-1934 & $10(8)$ & $1-47$ & 0.268 \\
\hline Quincy Bluff & 1694-1848 & $3(45)$ & $1-9$ & 1852-1930 & $3(25)$ & $1-10$ & 0.594 \\
\hline Wisconsin Dells & $1681-1850$ & $4(44)$ & $1-9$ & 1853-1924 & $5(13)$ & $1-11$ & 0.232 \\
\hline \multicolumn{8}{|c|}{ Blufflands and Coulees } \\
\hline Pine Bluff & $1684-1847$ & $4(45)$ & $1-11$ & $1851-1895$ & $9(5)$ & $4-17$ & 0.008 \\
\hline \multicolumn{8}{|l|}{ Northern Highlands } \\
\hline Cathedral Point & $1797-1846$ & $6(4)$ & $1-14$ & 1851-1908 & $x$ & $x$ & $x$ \\
\hline Frog Lake & $1833-1846$ & x & x & 1855-1941 & $7(12)$ & $1-15$ & $x$ \\
\hline Squirrel River & $1744-1847$ & $10(10)$ & $1-31$ & 1855-1910 & $7(8)$ & $3-15$ & 0.870 \\
\hline Finnerud Pines & $1736-1842$ & $8(13)$ & $1-18$ & 1850-1907 & $11(5)$ & $2-16$ & 0.172 \\
\hline Buckatabon & $1697-1845$ & $9(17)$ & $1-38$ & 1854-1910 & $7(8)$ & $1-15$ & 0.447 \\
\hline \multicolumn{8}{|l|}{ Northeast Sands } \\
\hline Camp Bird & $1764-1840$ & $8(10)$ & $1-14$ & 1860-1925 & $4(16)$ & $1-9$ & $0.046^{*}$ \\
\hline Wolf Lane & $1818-1843$ & $x$ & $x$ & 1850-1926 & $6(13)$ & $3-16$ & $x$ \\
\hline Tar Dam Road & $1714-1840$ & $11(12)$ & $3-31$ & $x$ & x & x & $x$ \\
\hline \multicolumn{8}{|c|}{ Keweenaw-Baraga Moraines } \\
\hline Bears Den & $1721-1829$ & $14(8)$ & $1-31$ & 1884-1909 & $6(4)$ & $3-11$ & 0.943 \\
\hline Pine Bluff Trail & 1659-1829 & $11(16)$ & $1-26$ & 1862-1927 & $7(9)$ & $1-22$ & 0.833 \\
\hline \multicolumn{8}{|c|}{ Grand Marais Lakeshore } \\
\hline Betchler Lake & $1548-1835$ & $9(32)$ & $1-32$ & 1853-1934 & $7(10)$ & $2-18$ & 0.802 \\
\hline Bay View & $1777-1848$ & $8(9)$ & $2-25$ & 1856-1932 & $8(9)$ & $3-13$ & 0.189 \\
\hline Hwy 13 & $1574-1846$ & $10(25)$ & $1-70$ & 1857-1910 & x & x & $x$ \\
\hline Corner Lake & 1699-1812 & $14(8)$ & $1-36$ & $1896-1946$ & $7(7)$ & $1-20$ & 0.798 \\
\hline \multicolumn{8}{|c|}{ Seney-Tahquamenon Sand Plain } \\
\hline Ramsey Lake & $1637-1847$ & $10(21)$ & $1-34$ & 1856-1932 & $10(5)$ & $9-12$ & 0.121 \\
\hline
\end{tabular}

historical accounts of settlement era fires; however, my interest was primarily to document general agreement between well-known historical events and fire scar reconstructed fires. Three of the four largest settlement era fire years reconstructed via fire scars (based on proportion of ecoregions recording a fire year and filtering of composited fire chronology for all samples) coincided with large fires described in historical accounts. These include (from most widespread to least): 1891, 1910, and 1920 (Table 4, Fig. 5). While fires in 1894 were found in half of ecoregions (Table 4), fire scar records indicate that 1895 was a more widespread fire year (Fig. 5). Both 1894 and 1895 were drought years (averaged PDSI $=-2.008,-2.380$ respectively). All but one historically documented fire year, 1931, which was a severe regional drought year (PDSI $=-3.424)$, were detected by fire-scars. Fire scar evidence in 1871, one of the more destructive settlement era fire years, did not indicate it as one of the more extensive fire years. Notably, fire scar records of this fire year, and all fire years detected by fire-scar methods, are primarily limited to low- and/or moderate-severity fires that scar trees without killing them (Kent 2014). Such records are consistent with more comprehensive maps showing a more extensive fire footprint than the relatively limited 

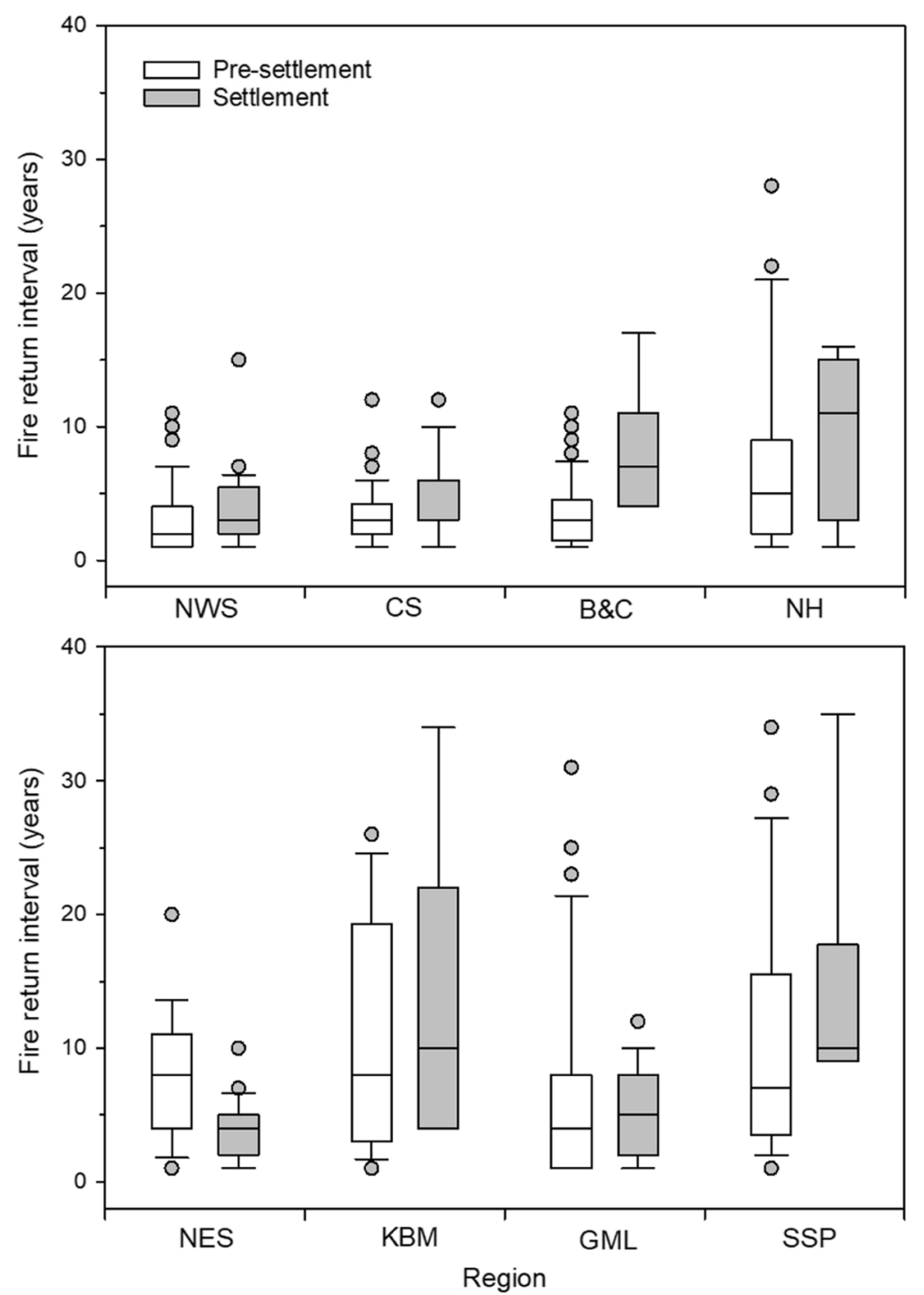

Fig. 3 Boxplot of median, interquartile ranges, 90th percentiles, and outliers for pre-settlement ( $\leq 1850)$ and settlement (> 1850) era fire return intervals by region ( $n=8$, arranged west to east, Northwest Sands—NWS, Central Sands—CS, Blufflands and Coulees—B\&C, Northern Highlands— NH, Northeast Sands_NES, Keweenaw-Baraga Moraines_KBM, Grand Marais Lakeshore_GML, Seney-Tahquamenon Sand Plain—SSP)

area impacted by high-severity Peshtigo Fire (Fig. 2b). Both large fire-scar reconstructed fire years (Fig. 5) and notable fires via historical accounts (Table 4) were significantly related to dry conditions (Fig. 6).

The Peshtigo Fire is somewhat unique in that there are detailed fire perimeter maps allowing at least qualitative analysis of fire-vegetation-climate relationships. Settlement era witness tree maps of the Peshtigo Fire region indicated that portions of the 1871 fires were a mesic "sugar bush" - a colloquial term for maple (Acer) forest used for syrup production (e.g., Lower, Upper, and Middle Sugarbush; Fig. 2a). The most abundant tree species out of 11,014 witness trees identified in the footprint of the Peshtigo Fire at the time of GLO Public Land Survey (ca. 10years prior to the fire) was hemlock (Tsuga canadensis; 21\%), followed by cedar (Thuja occidentalis; 14\%), beech (Fagus grandifolia; 12\%), tamarack (Larix laricina; 8\%), and sugar maple (Acer saccharum; 8\%; Fig. 7). Less than $10 \%$ of witness trees in the footprint of the Peshtigo fire were merchantable pine of any kind (most of which was white pine-a common component of mesic hardwoods; Curtis 1959). This region was and remains dominated by mesic forests (Wisconsin Department of Natural Resources, 2015) which were not harvested at any scale until a decade or more following the Peshtigo fire (Stearns 1997). 
Table 3 Summary of regression models analyzing temporal trends in fire activity for 25 different sites using a decadal fire index (DFI, mean number of fire scars per recording tree, per decade)

\begin{tabular}{|c|c|c|c|c|c|c|c|}
\hline & \# Samples & \# Fires & Time period & \# decades & $R^{2}$ & Trend & $P$-value \\
\hline \multicolumn{8}{|l|}{ Northwest Sands } \\
\hline Totogatic River & 27 & 206 & 1710-1949 & 25 & 0.211 & - & 0.024 \\
\hline Inch Lake & 34 & 1278 & 1660-1929 & 27 & 0.067 & 0 & 0.193 \\
\hline Lampson Pines & 14 & 96 & 1740-1959 & 22 & 0.060 & 0 & 0.274 \\
\hline Sand Lake & 29 & 270 & 1730-1889 & 16 & 0.211 & 0 & 0.074 \\
\hline \multicolumn{8}{|l|}{ Central Sands } \\
\hline Bruce Mound & 59 & 219 & 1680-1939 & 26 & 0.035 & 0 & 0.363 \\
\hline Wildcat Ridge & 49 & 216 & 1770-1888 & 12 & 0.813 & - & $<0.001$ \\
\hline Stoney Bluff & 20 & 118 & 1700-1939 & $23^{*}$ & & 0 & 0.320 \\
\hline Quincy Bluff & 23 & 180 & 1850-1930 & 29 & 0.011 & 0 & 0.585 \\
\hline Wisconsin Dells & 28 & 225 & 1680-1924 & 25 & 0.226 & - & 0.016 \\
\hline \multicolumn{8}{|c|}{ Blufflands and Coulees } \\
\hline Pine Bluff & 17 & 168 & 1680-1899 & & 0.325 & - & 0.006 \\
\hline \multicolumn{8}{|l|}{ Northern Highlands } \\
\hline Catherdral Point & 24 & 60 & 1790-1909 & 12 & 0.464 & - & 0.015 \\
\hline Frog Lake & 14 & 53 & 1830-1949 & 12 & 0.568 & - & 0.005 \\
\hline Squirrel River & 16 & 48 & 1740-1919 & 18 & 0.002 & 0 & 0.867 \\
\hline Finnerud Pines & 39 & 147 & 1690-1909 & 22 & 0.019 & 0 & 0.540 \\
\hline Buckatabon & 15 & 45 & 1690-1919 & & 0.032 & 0 & 0.418 \\
\hline \multicolumn{8}{|l|}{ Northeast Sands } \\
\hline Camp Bird & 17 & 141 & 1760-1929 & 17 & 0.000 & 0 & 0.939 \\
\hline Wolf Lane & 16 & 109 & 1810-1929 & 12 & 0.172 & 0 & 0.181 \\
\hline Tar Dam Road & 25 & 151 & 1710-1859 & 15 & 0.336 & - & 0.024 \\
\hline \multicolumn{8}{|c|}{ Keweenaw-Baraga Moraines } \\
\hline Bears Den & 13 & 40 & 1720-1909 & 19 & 0.001 & 0 & 0.908 \\
\hline Pine Bluff Trail & 11 & 42 & 1650-1929 & 28 & 0.019 & 0 & 0.481 \\
\hline \multicolumn{8}{|c|}{ Grand Marais Lakeshore } \\
\hline Betchler Lake & 62 & 190 & 1540-1959 & 42 & 0.041 & 0 & 0.200 \\
\hline Bay View & 15 & 67 & 1770-1939 & 17 & 0.015 & 0 & 0.643 \\
\hline Highway 13 & 15 & 73 & 1570-1910 & 35 & 0.032 & 0 & 0.302 \\
\hline Corner Lake & 20 & 60 & 1699-1949 & 26 & 0.001 & 0 & 0.867 \\
\hline \multicolumn{8}{|c|}{ Seney-Tahquamenon Sand Plain } \\
\hline Ramsey Lake & 41 & 133 & 1630-1939 & 31 & 0.035 & 0 & 0.316 \\
\hline
\end{tabular}

\section{Discussion}

Understanding disturbance regimes in relation to climate and land use change is vital for fostering resilient ecosystems that can accommodate an uncertain future (Landres et al. 1999). Historical context is needed to interpret past and potential climate change influences on disturbance processes but is reliant on robust historical baseline data. The need for robust baselines is particularly acute for ecosystems with highly altered disturbance regimes (Higgs et al. 2014; Knight et al. 2020). The Lake States have highly altered disturbance regimes (Meunier et al., 2019a, b) as well as an aberrant settlement reference period when rapid and intense land use changes were pervasive. It was assumed, for example, that settlement era fires were anomalous with more frequent and severe fires resulting from cutover slash (White and Host 2008); yet there is little evidence for slash as a widespread and prolonged fire hazard (Zon and Cunningham 1931) and little or no evidence that fire was more frequent in the settlement period (Tables 2 and 3, Figs. 3, 4, and 5). Fuel type (e.g., forest composition), in addition to fuel loading (e.g., slash), needs to be considered in relation to fire severity, particularly for destructive settlement era fires like the October 1871 Peshtigo fire. The assumption that fires were another (or the) degrading force of forest following exploitative settlement era land-use 


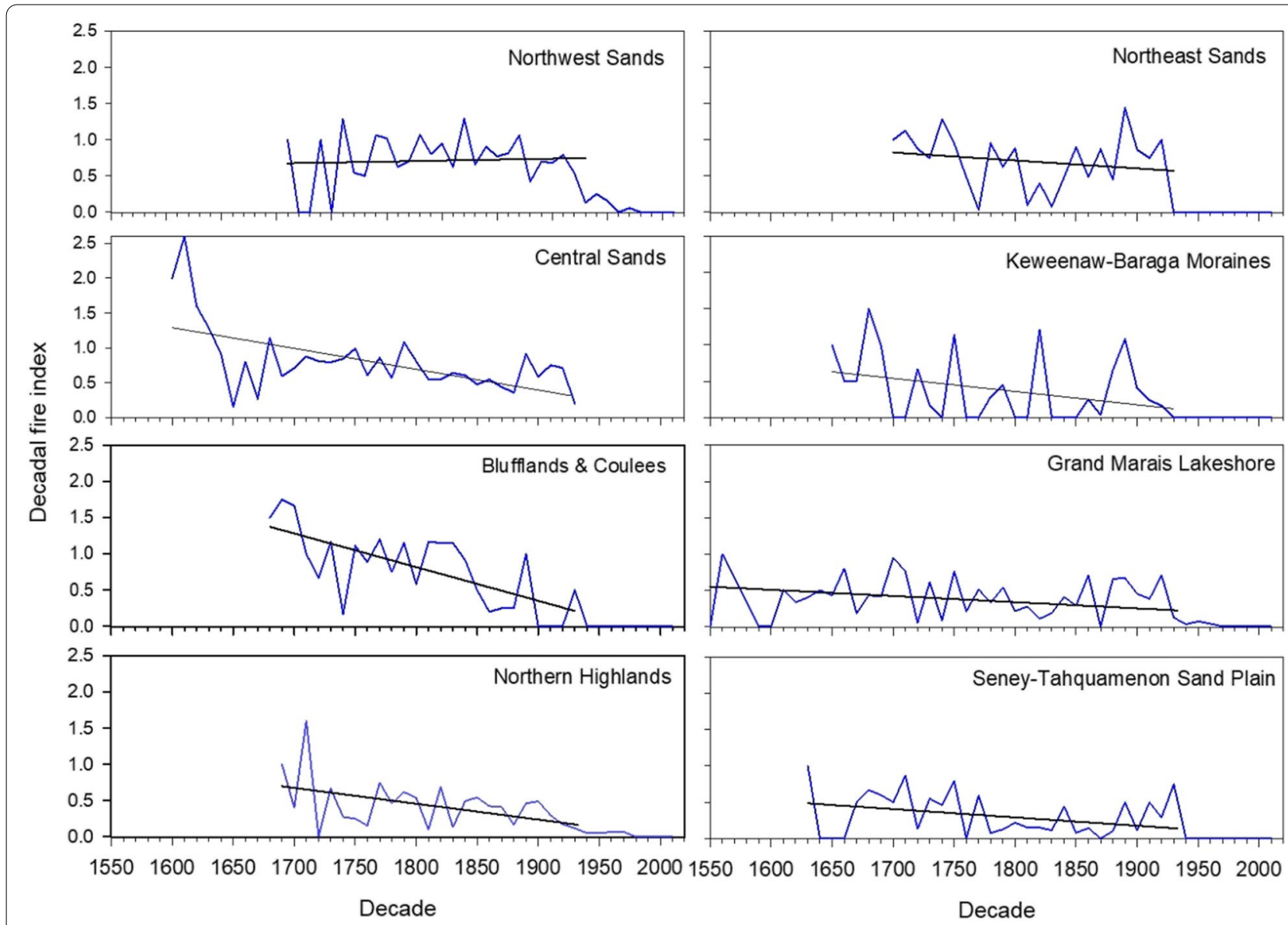

Fig. 4 Decadal fire indices for sites $(n=25)$ composited by region $(n=8)$. Slopes are linear regression lines for the period of first recorded fires to 1930. Only the Bluff \& Coulee (B\&C) and Central Sands (CS) regions had slopes significantly different than would be expected by chance $(P<0.001)$

changes (Johnson 2020) may be fundamentally flawed and formed, in part, by ignorance of basic historical fire regime characteristics in Lake State forests.

In the context of a longer (ca. 400-year) fire history, settlement era fires were not uncharacteristically frequent nor is there an obvious relationship between fire frequency and slash (Zon and Cunningham 1931). Only one out of 25 sites, Camp Bird in the Northeast Sands (NES), had a significantly shorter fire return interval in the settlement period (Table 2, Fig. 3), and that site was a neverharvested old growth pine stand where slash would have been absent. In most cases fires were less, not more, frequent in the settlement era (Tables 1 and 2, Figs. 3 and 4). Interestingly, many of the same settlement era fires attributed to slash are documented in unharvested portions of the Boundary Waters Canoe Area Wilderness (BWCAW; Heinselman 1973) and also the 95,313 ha Menominee Indian Reservation (Sands and Abrams 2011). In spite of never having had exploitative logging on the Menominee Reservation, Sands and Abrams (2011) documented 36 settlement era fires between 1850 and 1910, 14 of which are synchronous with notable historical accounts of settlement fires in the region: 1854, 1864, 1868, 1871, 1879, $1881,1887,1891,1893,1894,1896,1898,1900$, and 1910 (Table 4). Settlement fires in the "virgin" BWCAW forests are also very similar to elsewhere in the Lake States region (e.g., 1854, 1863-1864, 1868, 1871, 1874-1875, $1880-1881,1887,1894,1900,1910,1918,1920,1936$; Heinselman 1973). Importantly, settlement era fires in the BWCAW are generally not viewed as anomalous, in part due to the foundational fire history work by Heinselman (1973), which provided greater context to the incidence of fire there.

Several studies have suggested that the combination of logging and slash fires followed by fire suppression in the 1930s drastically altered forest composition in the Lake States (Miller et al. 2010) and led to a loss of coniferous species and increase in deciduous species in northern Wisconsin (Mladenoff and Howell 1980; White and Mladenoff 1994; Radeloff et al. 1999; Steen-Adams et al. 2007). However, it remains unclear what the relative contributions of logging, slash fires, or subsequent fire 
Table 4 Notable Euro-American settlement era wildfires in the Lake States organized by percentage of ecoregions $(n=8)$ in Wisconsin and the Upper Peninsula of Michigan detected with fire-scars and then chronologically

\begin{tabular}{|c|c|c|c|}
\hline Fire Year & States & $\%$ Regions & Event(s) \\
\hline 1891 & $\mathrm{Wl}, \mathrm{Ml}$ & 78 & Comstock Fire 260 km² —WI (May) \\
\hline 1910 & $\mathrm{MN}, \mathrm{WI}, \mathrm{Ml}$ & 67 & Baudette-Spooner Fire-2nd largest in MN (Oct.) \\
\hline 1900 & Wl & 56 & Chequamegon Bay, Menominee River (May) \\
\hline 1864 & $\mathrm{MN}, \mathrm{Wl}$ & 44 & Little Souix (BWCAW')—MN, northcentral WI \\
\hline 1868 & Wl & 44 & Fires in northcentral, Kewaunee and Door counties NE (Sep.) \\
\hline 1894 & $\mathrm{MN}, \mathrm{Wl}$ & 44 & Phillips Fire—-8 counties in WI (Jul.); Hinckley Fire, Lac La Croix Fire (BWCA)—largest in MN (Sep.) \\
\hline 1918 & MN & 44 & Cloquet-Moose Lake Fire—4th largest in MN \\
\hline 1923 & WI & 44 & Fires \\
\hline 1854 & Wl & 33 & Single fire runs from Amery to Iron River, $225 \mathrm{~km}$ \\
\hline 1863 & $\mathrm{MN}, \mathrm{WI}$ & 33 & Alice-Saganaga Fire-3rd largest in MN > $1000 \mathrm{~km}^{2}$ \\
\hline 1871 & $\mathrm{Wl}, \mathrm{Ml}$ & 33 & Peshtigo Fire —WI (Oct.), Great MI Fire $>10,000$ km² (Oct.) $^{2}$ \\
\hline 1881 & $\mathrm{Ml}$ & 33 & $3885 \mathrm{~km}^{2}$-Ml thumb (Sep.) \\
\hline 1897 & Wl & 33 & Fires \\
\hline 1908 & $\mathrm{Wl}, \mathrm{Ml}$ & 33 & $\begin{array}{l}\text { Mosinee (1907-1908), Wausau, Rhinelander, Bayfield-WI (Apr.); Chisholm Fire-MN (Sep.); Metz } \\
\text { Fire_Lower MI (Oct.) }\end{array}$ \\
\hline 1920 & WI & 33 & "Widespread fire"—Central Sands; major losses Douglas County—NWS (Oct.) \\
\hline 1936 & $\mathrm{Wl}, \mathrm{Ml}$ & 33 & "Worst year of fires in Upper Peninsula" (UP) MI \\
\hline 1874 & $\mathrm{Ml}$ & 22 & Major fire year-lower central Ml \\
\hline 1875 & $\mathrm{MN}$ & 22 & Insula Ogishkemuncie (BWCAW ${ }^{a}$ ) \\
\hline 1879 & $\mathrm{Ml}$ & 22 & Major fire year-lower central Ml \\
\hline 1880 & WI & 22 & Sep. fires \\
\hline 1887 & WI & 22 & Marshfield burned (Jun.) \\
\hline 1893 & Wl & 22 & "A disastrous fire" Central Sands \\
\hline 1896 & $\mathrm{Wl}, \mathrm{Ml}$ & 22 & Ironwood, Hurley-Wl; Ontonagon fire (>900 km²)-UP MI \\
\hline 1898 & Wl & 22 & Barron and Polk Counties—WI (Sep.) \\
\hline 1930 & Wl & 11 & $1295 \mathrm{~km}^{2}$ burned in Central Sands \\
\hline 1931 & $\mathrm{MN}, \mathrm{Wl}$ & 0 & Red Lake "Dust Bowl"Fire-MN (Sep.) \\
\hline
\end{tabular}

a Boundary Waters Canoe Area Wilderness (BWCA). Sources: WI Historical Society, Minnesota Division of Forestry, 1965, Heinselman 1973, Stearns 1997, Pyne 2001, Dickmann and Leefers 2003, U.S. Fish and Wildlife Service, 2004, Brown 2009, Apps 2020

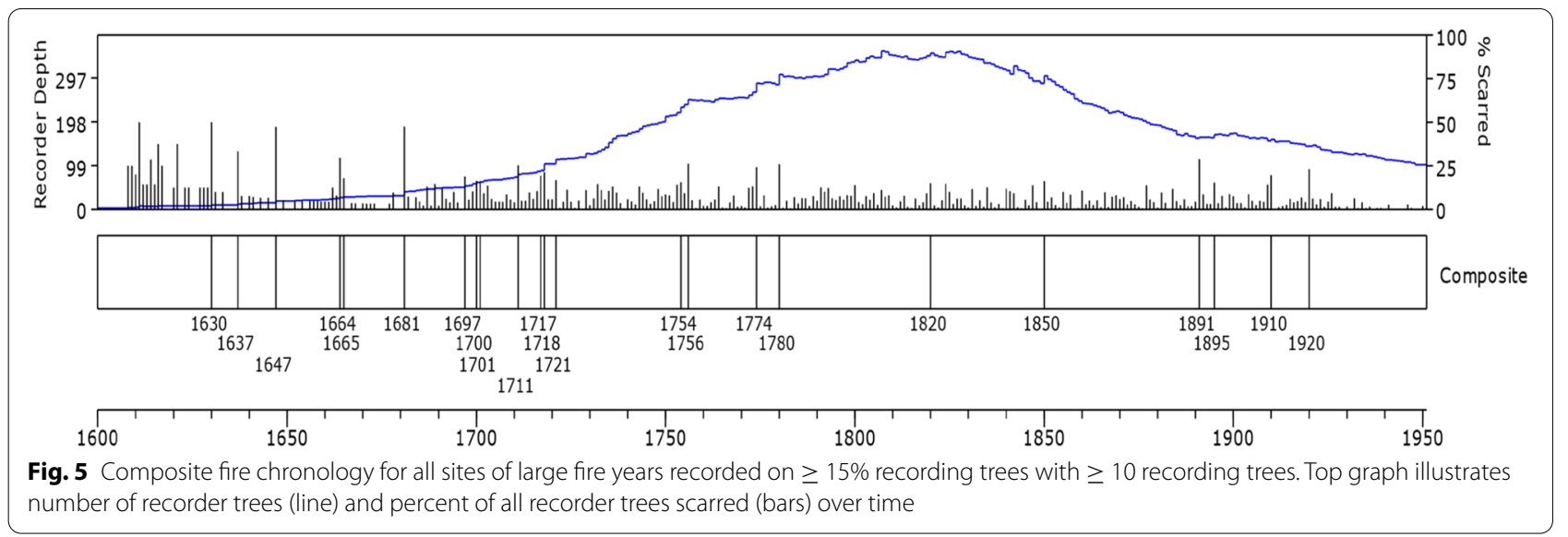

suppression were to these changes (White and Mladenoff 1994; Rhemtulla et al. 2009). Cook (2000) found that tree establishment dates in Lake States pine-oak forest peaked following logging and fires, particularly between 1891 and 1911, which include some of the most widespread settlement era fire years (e.g., 1891, 1894-1895, and 1910; 


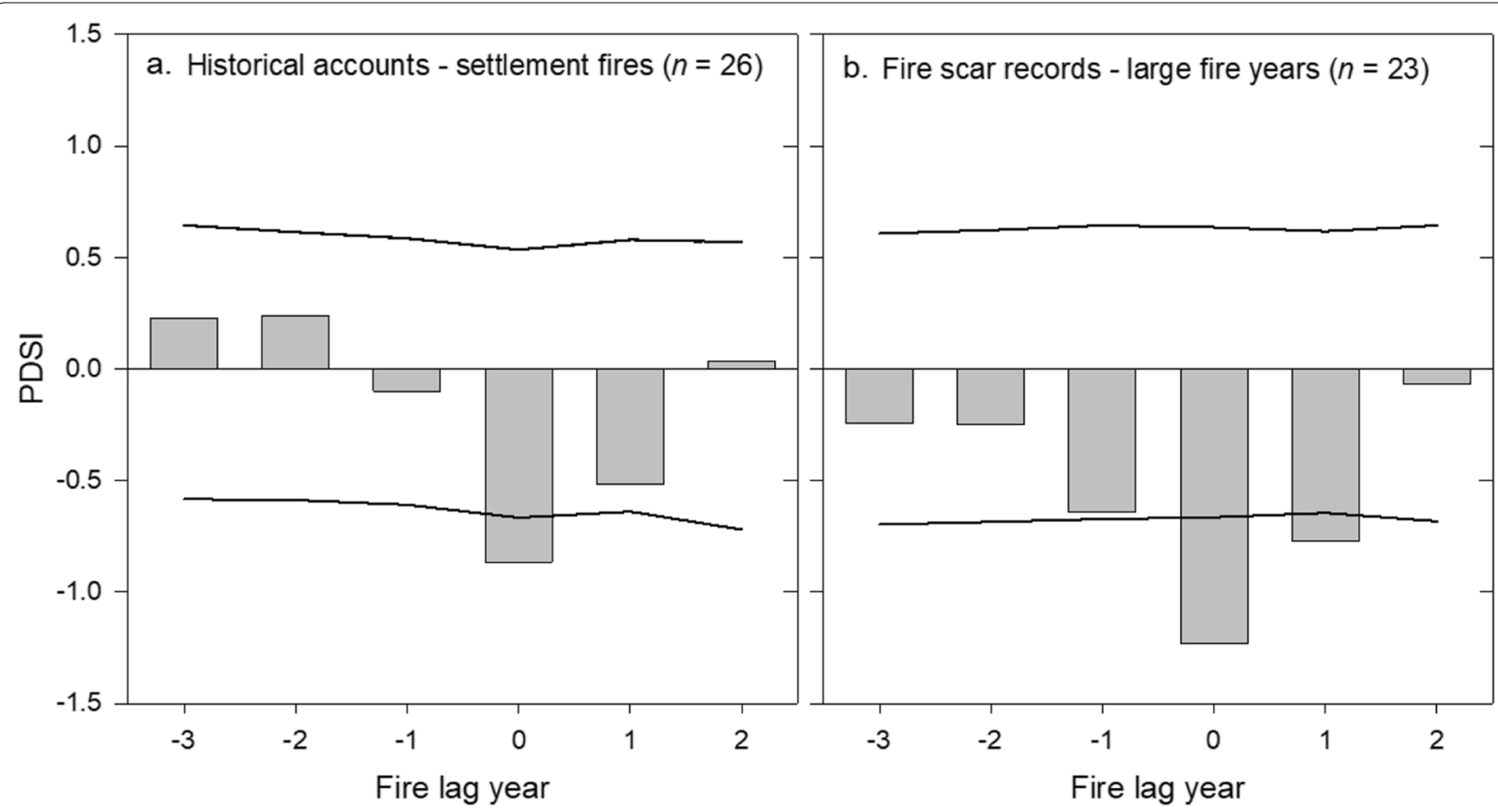

Fig. 6 Results of superposed epoch analysis (SEA) of the average Palmer Drought Severity Index (PDSI) across the region (Cook et al. 2007) for years prior and subsequent to fire event years (year 0 ) for $\mathbf{a}$ notable historical accounts of settlement era fires (i.e., Table 4 ) and $\mathbf{b} \geq 15 \%$ average rate of scarring (minimum 10 recording trees) across all ecological landscapes. Positive PDSI values indicate wet conditions, negative values represent dry conditions. Solid bars indicate PDSI values outside a 95\% confidence interval based on 1000 Monte Carlo simulations of random distributions of annual PDSI (a 1850-1950, b 1600-2000)

Table 4, Fig. 5). Close coupling between tree recruitment and low-severity fires, including in the settlement period, was also noted in the BWCAW (Heinselman 1973). In a study in western Oregon and Washington, effects of slash burning following clearcut harvesting had little effect on the quantity of natural stocking of conifers and subsequent hazard rating was lower on burned than unburned plots (i.e., lower spread rate and more easily controlled; Morris 1970). Remarkably, while land use history varied across the disparate forests and ecoregions in this study (e.g., different composition, harvested or not, timing and intensity of harvest), two factors are common among all locations: fire was historically frequent, and fire was universally excluded by the mid-twentieth century (Table 1 ). It is likely that 100 years of fire suppression, rather than a period of more frequent fires, were primary drivers of expansive forest changes (Paulson et al. 2016).

It seems that fires in the Lake State were influenced by abundant fuels and, periodically, extended drought conditions. The relationship between settlement land use changes and fire severity remains an unresolved issue; however, it is known, at least in theory, that many Lake State conifer forests inherently have heavy fuel loads (canopy and surface fuels) where fire behavior is controlled more by weather at the time of fire than by any other factor (Bessie and Johnson 1995; Frelich 2002). Cutting (and windthrow) can change fuel moisture of slash, which can effect flame length and potentially increase fire severity (Evans and Wright 2017). Fuel moisture of slash increases with compaction over time which acts counter to combustion dynamics (Wright et al. 2019). Fuels also tend to decompose much faster in eastern forests, with higher productivity (moisture and temperature) than in most of the western US (Graham and McCarthy 2006) where fuel accumulation increases risk of high intensity fire. Notably, the 1871 fires in Wisconsin had been burning for many weeks prior to October with little rain since the early part of July and below average snowfall in winter of 1870-1871 (Gess and Lutz 2003). Residents described a constant crackling of fire at night and smoke was omnipresent (Pernin 1971). These fires were primarily lower severity, much of which burned pine forests to the north of the high severity October 8 Peshtigo Fire (e.g., northern Oconto and Marinette Counties), where presumably slash would have been present (Fig. 2b). These low severity fires of 1871 were detected across study sites in Wisconsin (NWS, CS, NES), the Menominee Indian Reservation to the northeast (Sands and Abrams, 2011), and in the Huron Mountains in the Upper Peninsula of Michigan (Muzika et al. 2015). 


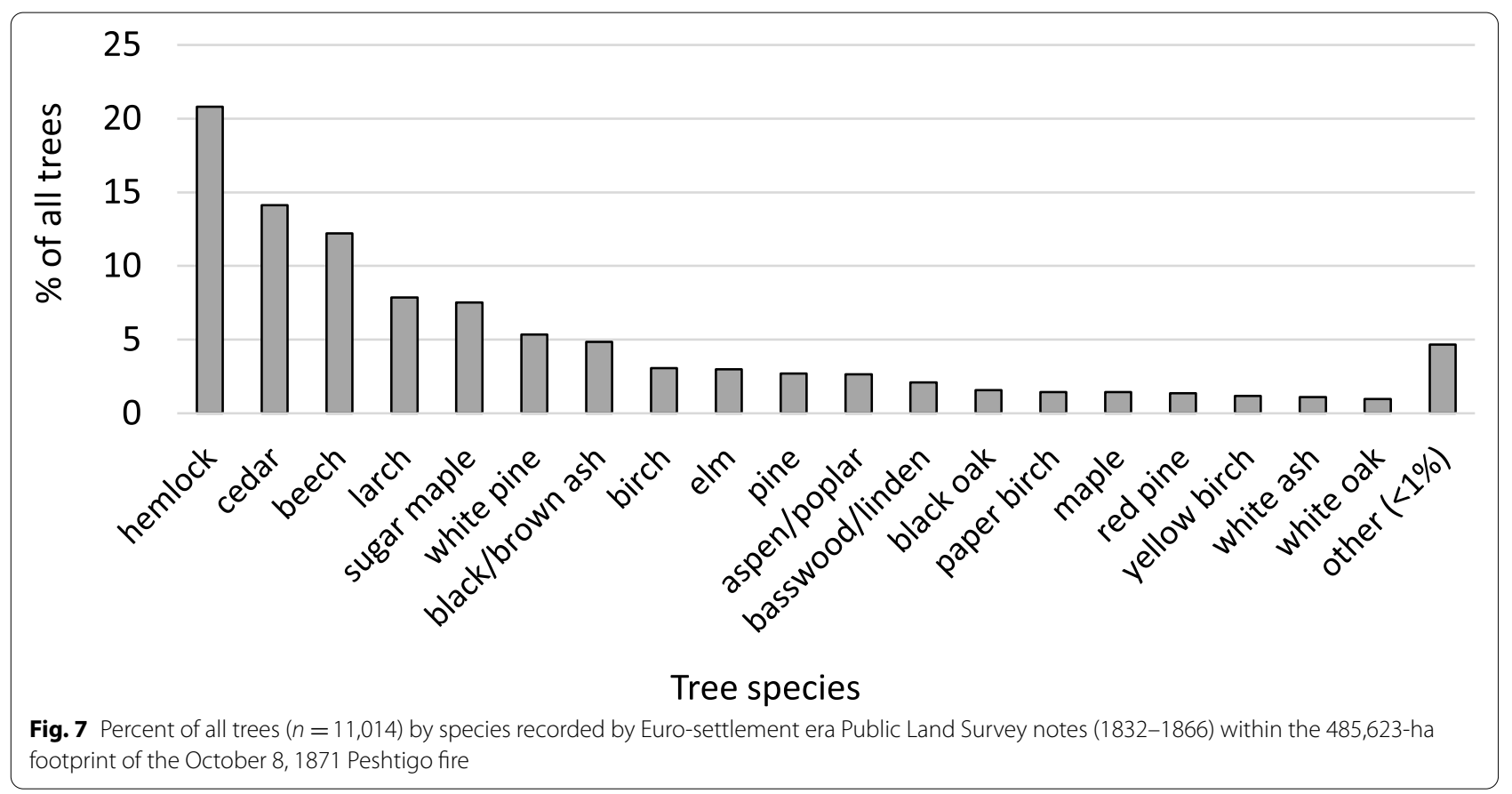

Schulte and Mladenoff (2005) in their analysis of GLO data found that stand-replacing fires were never recorded by surveyors within the ecological landscapes associated with the October 8, 1871 Peshtigo Fire (Fig. 2a). Wildfire frequency and intensity are broadly inversely related (Pickett and White 1985; Turner et al. 1989). Fire regimes in many forested systems can be categorized as ranging from "fuel-limited" to "climate-limited," where the former are characterized by more frequent, lower-severity wildfires and the latter by infrequent, more severe wildfires (Steel et al. 2015). The mesic forests of the Peshtigo Fire region (Fig. 7) would be expected to burn infrequently and with high severity. It is not surprising that GLO survey data would not detect fires in this landscape which would be characterized by infrequent fires nor is it surprising that this landscape would burn with the intensity and devastation that it did with abundant natural fuel loads (e.g., hemlock, cedar, larch forests). In 1871, logging was still restricted to river lumbering of pine, and while land clearing was associated with settlement, it would likely have been limited in comparison to the ca. $5000 \mathrm{~km}^{2}$ area burned. Very little logging had occurred within the Peshtigo Fire footprint, and slash from logging would not have been abundant there in 1871. Regardless of the contributions of settlement activities to the Peshtigo Fire, high-severity fires would be expected to predominate in forests there. Notably, the high-severity Peshtigo Fire represents a relatively small proportion of area embedded within a larger burn area that burned as low-severity fire in that same year (Fig. 2b).
In 1871, there was prolonged regional drought (average PDSI $1871=-2.364,1870=-2.470$ ) where fires had been burning for more than a month, which were then fanned by strong southeasterly winds (National Oceanic and Atmospheric Administration, National Weather Service, 2021) into an abnormally dry forest with abundant fuels. This story is not unique to the Peshtigo Fire or to 1871 , but rather it was the way many large fire years burned over the last 400 years in the Lake States (Figs. 5 and 6). While land use changes in relation to wildfires occurring during settlement in the Lake States cannot be discounted, they also cannot explain scores of similar fire years, over widely varying landscapes, and over centuries (Fig. 5).

Historical reference information is valuable for understanding how current conditions arose, as well as for developing a mechanistic understanding of ecosystem dynamics and predicting future conditions (Safford et al. 2012; Miller and Safford 2017). Historical data, like written accounts at the time of Euro-American settlement, or settlement era Public Land Survey data, can be useful in describing the magnitude of change in conditions relative to reference landscapes (Rhemtulla et al. 2009). However, such data are not always useful in assessing the drivers of change or in forecasting future conditions (Frelich 2002). Likewise, a single "settlement" reference is a static view of ecosystems that were and remain inherently dynamic. What becomes apparent when considering a longer history and greater context is that frequent fires were one of few continuities within forests of the Lake States during 
settlement. This is a starting point for unraveling the effects of the myriad degrative land uses in the settlement period and for understanding the contradictions of defining forest conservation in the Lake States on the premise of fire suppression. Although the nature of future forests will be determined in part by climate change and other exogenous variables, land use and fire have been and are likely to remain the driving factors in shaping forests (Rhemtulla et al. 2009). The question is what type of land uses and what type of fire will be part of those future forests.

\section{Conclusions}

Settlement era fires (ca. 1851-1947) were believed to have been abnormally frequent and primarily a result of slash build up following extensive cut-over of Lake States forests. However, historically (over the last 400 years), fires were always relatively frequent, occurring on average every 8 years (MFRI $=3-15$ years). Settlement fires in the Lake States were not simply slash fires, but a combination of weather, climate, and fuel arrangements. Large fires tended to correspond to extended drought conditions regardless of time period. Destructive fires in the Lake States, like the October 8, 1871, Peshtigo Fire, burned in mesic forests where large volumes of pine slash would not have been present; however, large volumes of fuels were always present and where fires would be expected to burn with high severity.

\begin{abstract}
Abbreviations
B\&C: Blufflands and Coulees ecoregion; BWCAW: Boundary Waters Canoe Area Wilderness; CS: Central Sands ecoregion; DFI: Decadal fire index; GML: Grand Marais Lakeshore ecoregion; KBM: Keweenaw-Baraga Moraines ecoregion; LANDFIRE: Landscape Fire and Resource Management Planning Tools; MFRI: Mean fire return interval; NES: Northeast Sands ecoregion; NH: Northern Highlands ecoregion; NOAA NWS: National Oceanic and Atmospheric Administration National Weather Service; NWS: Northwest Sands ecoregion; PDSI: Palmer Drought Severity Index; UP: Upper Peninsula, Michigan; USA: United States of America; U.S. Forest Service: United States Forest Service; SEA: Superposed epoch analysis; SSP: Seney-Tahquamenon Sand Plain ecoregion; WI: Wisconsin; WI DNR: Wisconsin Department of Natural Resources; WMPI: Wiebull Median Probability Interval.
\end{abstract}

\begin{abstract}
Acknowledgements
I thank the WI DNR Office of Applied Science, WI DNR Division of Forestry, and USFWS Pittman-Robertson Wildlife Restoration Program for supporting this work. I am grateful for early reviewers of this manuscript including John Lampereur, Steve Pyne, Colleen Sutheimer, Tricia Fry, and Curt Meine. I would like to acknowledge the many field technicians who helped with data collection including B. Selz, D. Ladd, M. Ruminski, J. Lois, S. Kovach, A. Lenoch, and M. Hertisch. I am particularly indebted to C. Sutheimer, N. Holoubek, P. Brown, and J. Riser who helped with compiling fire history as well as Ivy Widick who helped with analysis of General Land Office data. I also thank the anonymous reviewers for Fire Ecology that greatly improved this paper.
\end{abstract}

\section{Author's contributions}

All data analysis, presentation, ideas, and writing are by Dr. Jed Meunier. The author read and approved the final manuscript.
Funding

Support from institutional funds.

\section{Availability of data and materials}

The datasets used and/or analyzed during the current study are available from the corresponding author on reasonable request.

\section{Declarations}

Ethics approval and consent to participate

Not applicable

Consent for publication

Not applicable

Competing interests

The author declares that they have no competing interests.

Received: 20 September 2021 Accepted: 3 February 2022

Published online: 07 March 2022

\section{References}

Apps, J. 2020. When the white pine was king: a history of lumberjacks, log drives, and sawdust cities in Wisconsin, 184. Wisconsin Historical Society, Madison, WI ISBN 0870209353.

Bessie, W.C., and E.A. Johnson. 1995. The relative importance of fuels and weather on fire behavior in subalpine forests. Ecology 76: 474-762.

Bormann, F.H., and G.E. Likens. 1979. Pattern and process in a forested ecosystem. New York: Springer-Verlag.

Brewer, P.W., M.E. Velásquez, E.K. Sutherland, and D.A. Falk. 2019. Fire History Analysis Exploration System (FHAES) version 2.0 [software]. http://www. fhaes.org. https://doi.org/10.5281/zenodo.

Brose, P., T. Schuler, D. Van Lear, and J. Berst. 2001. Bringing fire back — the changing regimes of the Appalachian mixed-oak forests. Journal of Forestry 99 (11): 30-35.

Brown, D.J. 2009. Under a flaming sky: the great Hinckley firestorm of 1894. Guilford: The Lyons Press.

Cheyney, E.G. 1939. Slash again in the Lake States. Journal of Forestry 37: 640-641.

Comer, P.J., D.A. Albert, H.A. Wells, B.L. Hart, J.B. Raab, D.L. Price, D.M. Kashian, R.A. Corner, D.W. Schuen, M.B. Austin, T.R. Leibfreid, K.M. Korroch, L. Prange-Gregory, J.G. Spitzley, C.J. DeLain, and L.J. Scrimger. 1995. Michigan's presettlement vegetation, as interpreted from the General Land Office Surveys 1816-1856. Lansing: Michigan Natural Features Inventory.

Cook, E.R., R. Seager, M.A. Cane, and D.W. Stahl. 2007. North American drought: reconstructions, causes and consequences. Earth-Science Reviews 81: 93-134.

Cook, J.E. 2000. Disturbance history of two natural areas in Wisconsin: implications for management. Natural Areas Journal 20 (1): 24-35.

Cronon, W. 1983. Changes in the land: Indians, colonists, and the ecology of New England. New York: Hill and Wang.

Curtis, J.T. 1959. The Vegetation of Wisconsin. Madison: The University of Wisconsin Press.

Dickmann, D.I., and D.T. Cleland. 2002. Fire return intervals and fire cycles for historic fire regimes in the Great Lakes Region: a synthesis of the literature. Research Report, Great Lakes Ecological Assessment, Washington D.C. USA.

Dickmann, D.I., and L.A. Leefers. 2003. The forests of Michigan, 153-157. Ann Arbor: The University of Michigan Press.

Drever, C.R., G. Peterson, C. Messier, Y. Bergeron, and M. Flannigan. 2006. Can forest management based on natural disturbances maintain ecological resilience? Canadian Journal of Forest Research 36: 2285-2299.

Drobyshev, I., P.C. Goebel, D.M. Hix, R.G. Corace III, and M.E. Semko-Duncan. 2008. Interactions among forest composition, structure, fuel loadings and fire history: a case study of red pine-dominated forests of Seney National Wildlife Refuge, Upper Michigan. Forest Ecology and Management 256: 1723-1733. 
Environmental Systems Research Institute (ESRI). 2014. ArcGIS Desktop 10.3. Redlands, CA.

Evans, A.M., and C.S. Wright. 2017. Unplanned wildfire in areas with slash piles. Fire Management Today 75 (2): 25-29.

Farris, C.A., C.H. Baisan, D.A. Falk, S.R. Yool, and T.W. Swetnam. 2010. Spatial and temporal corroboration of a fire-scar-based fire history in a frequently burned ponderosa pine forest. Ecological Applications 20: 1598-1614.

Frelich, L.E. 2002. Forest dynamics and disturbance regimes. Cambridge: Cambridge University Press.

Fries, R. 1951. Empire of pine: the story of lumbering in Wisconsin, 1830-1900, viii, 285. Madison: The State Historical Society of Wisconsin.

Fritts, H.C., and T.W. Swetnam. 1989. Dendroecology: a tool for evaluating variations in past and present forest environments. Advances in Ecological Research 19: 111-188.

Gess, D., and W. Lutz. 2003. Firestorm at Peshtigo: a town, its people, and the deadliest fire in American history, 320. New York: Macmillan ISBN 978-0-8050-7293-8.

Gough, Robert. 1997. Farming the cutover: a social history of northern Wisconsin, 1900-1940, 320. Lawrence: University Press of Kansas.

Graham, J.B., and B.C. McCarthy. 2006. Effects of fine fuel moisture and loading on small scale fire behavior in mixed-oak forest of southeastern Ohio. Fire Ecology 2: 100-114.

Grissino-Mayer, H.D. 1999. Modeling fire interval data from the American southwest with the Weibull distribution. International Journal of Wildland Fire 9: 37-50.

Grissino-Mayer, H.D., and T.W. Swetnam. 2000. Century-scale climate forcing of fire regimes in the American Southwest. Holocene 10: 213-220.

Haines, D.A., and R.W. Sando. 1969. Climatic conditions preceding historically great fires in the North Central Region. U.S. Forest Service Research Paper NC-34. St. Paul, Minnesota: U.S. Dept. of Agriculture, Forest Service, North Central Forest Experiment Station.

Heinselman, M.L. 1973. Fire in the virgin forests of the Boundary Waters Canoe Area, Minnesota. Quaternary Research 3: 329-382.

Hessberg, P.F., C.L. Miller, S.A. Parks, N.A. Povak, A.H. Taylor, P.E. Higuera, S.J. Prichard, M.P. North, B.M. Collins, M.D. Hurteau, A.J. Larson, C.D. Allen, S.L. Stephens, H. Rivera-Huerta, C.S. Stevens-Rumann, L.D. Daniels, Z. Gedalof, R.W. Gray, V.R. Kane, D.J. Churchill, R.K. Hagmann, T.A. Spies, C.A. Cansler, R.T. Belote, T.T. Veblen, M.A. Battaglia, C. Hoffman, C.N. Skinner, H.D. Safford, and R.B. Salter. 2019. Climate, environment, and disturbance history govern resilience of western North American forests. Frontiers in Ecology and Evolution. https://doi.org/10.3389/fevo. 2019.00239

Higgs, E., D.A. Falk, A. Guerrini, M. Hall, J. Harris, R.J. Hobbs, S.T. Jackson, J.M. Rhemtulla, and W. Throop. 2014. The changing role of history in restoration ecology. Frontiers in Ecology and Environment 12: 499-506.

Higuera, P.E., J.T. Abatzoglou, J.S. Littell, and P. Morgan. 2015. The changing strength and nature of fire-climate relationships in the northern Rocky Mountains, U.S.A., 1902-2008. PLos One 10: e0127563.

Hoss, J.A., C.W. Lafon, H.D. Grissino-Mayer, S.R. Aldrich, and G.G. DeWeese. 2008. Fire History of a Temperate Forest with an Endemic Fire-Dependent Herb. Physical Geography 29: 424-441.

Johnson, B. 2020. Trail by fire: a cultural complacency, institutional learning, and the development of the fire warden system in Minnesota, 1870-1920, 17. Culminating Projects in History https://repository.stcloudstate.edu/ hist_etds/17. St. Cloud: St. Cloud State University.

Kates, J. 2001. Planning a wilderness: regenerating the Great Lakes cutover region, 207. Minneapolis: University of Minnesota Press.

Kent, L.Y. 2014. An evaluation of fire regime reconstruction methods, 15. Flagstaff: ERI Working Paper No. 32. Ecological Restoration Institute and Southwest Fire Science Consortium, Northern Arizona University.

Knight, C.A., C.V. Cogbill, M.D. Potts, J.A. Wanket, and J.J. Battles. 2020. Settlement-era forest structure and composition in the Klamath Mountains: reconstructing a historical baseline. Ecosphere 11(9). https://doi.org/10. 1002/ecs2.3250

Lafon, C.W., A.T. Naito, H.D. Grissino-Mayer, S.P. Horn, and T.A. Waldrop. 2017. Fire history of the Appalachian region: a review and synthesis. U.S. Department of Agriculture Forest Service Southern Research Station General Technical Report SRS-219. Asheville, NC.

LANDFIRE. 2016. Historical fire regime and vegetation departure. https://www. landfire.gov
Landres, P., P. Morgan, and F. Swanson. 1999. Overview of the use of natural variability concepts in managing ecological systems. Ecological Applications 9: 1179-1188.

Larson, L.E., and B.A. Larson. 2016. The enduring cutover contributions to the history of Wisconsin's northern region, 440. Whitewater: University of Wisconsin Whitewater.

Lorimer, C.G. 1980. The use of land survey records in estimating presettlement fire frequency. In Proceedings of the Fire History Workshop, October 20-24 1980, ed. M.A. Stokes and J.H. Dieterich, 57-62. Tucson: General Technical Report, RM-81, USDA Forest Service.

Marlon, J.R., P.J. Bartlein, D.G. Gavin, C.J. Long, R.S. Anderson, C.E. Briles, K.J. Brown, D. Colombaroli, D.J. Hallett, M.J. Power, E.A. Scharf, and M.K. Walsh. 2012. Long-term perspectives on wildfires in the western USA. Proceedings of the National Academy of Sciences of the United States of America USA 109: E535-E543.

Marquis, D.A. 1975. The Allegheny hardwoods forests of Pennsylvania. USDA Forest Service, Northeastern Forest Experimental Station, General Technical Report, NE-15. Upper Darby, PN.

Meunier, J., N.S. Holoubek, P.M. Brown, and M. Sebasky. 2019a. Re-evaluating pattern and process to understand resilience in transitional mixed conifer forests. Ecology 100: e02839.

Meunier, J., N.S. Holoubek, and M. Sebasky. 2019b. Fire regime characteristics in relation to physiography at local and landscape scales in Lake States pine forests. Forest Ecology and Management 454: 117651. https://doi. org/10.1016/j.foreco.2019.117651.

Meunier, J., and M.E. Shea. 2020. Applying the usual rules to an unusual ecological situation: fire rotation in Great Lakes pine forests. Forest Ecology and Management 472: 118246.

Meunier, Jed, Peter M. Brown, and William H. Romme. 2014. Tree recruitment in relation to climate and fire in northern Mexico. Ecology 95: 197-209.

Miller, A.M., I.J. Davidson-Hunt, and P. Peters. 2010. Talking about fire: Pikangikum First Nation elders guiding fire management. Canadian Journal of Forest Research 40: 2290-2301.

Miller, J.D., and H.D. Safford. 2017. Corroborating evidence of a pre-Euro-American low- to moderate-severity fire regime in yellow pine-mixed conifer forests of the Sierra Nevada, California, USA. Fire Ecology 13: 58-90.

Minnesota Division of Forestry. 1965. A history of forestry in Minnesota: with particular reference to forestry legislation, 109. Association of Minnesota Division of Lands and Forestry Employees. St. Paul, MN.

Mitchell, J.A., and N. LeMay. 1952. Forest fires and forest-fire control in Wisconsin. Wisconsin State Conservation Commission. 75 pp.

Mladenoff, D.J. 2009. See Wisconsin through the eyes of $19^{\text {th }}$ century surveyors. Madison: University of Wisconsin PUB-CE-4018.

Mladenoff, D.J., and E.A. Howell. 1980. Vegetation change in the Gogebic Iron Range (Iron County, Wisconsin) from the 1860's to present. Transaction of the Wisconsin Academy of Sciences Arts and Letters 68: 74-89.

Morris, W.G. 1970. Effects of slash burning in overmature stands of Douglas-fir region. Forest Science 16: 258-270.

Muzika, R.M., R.P. Guyette, M.C. Stambaugh, and J.M. Marschall. 2015. Fire, drought, and humans in a heterogeneous Lake Superior landscape. Journal of Sustainable Forestry 34: 49-70.

National Oceanic and Atmospheric Administration, National Weather Service. 2021. The Great Midwest fires of 1871. Accesses July 2021: https://www. weather.gov/grb/peshtigofire2.

Omernick, J.M., and G.E. Griffith. 2014. Ecoregions of the conterminous United States: evolution of a hierarchical spatial framework. Environmental Management 54: 1249-1266.

Omernik, J.M. 1987. Ecoregions of the conterminous United States. Map (scale 1:7,500,000). Annals of the Association of American Geographers 77: $118-125$.

Parks, S.A., L. Holsinger, C. Miller, and Marc-André Parisien. 2017. Analog-based fire regime and vegetation shifts in mountainous regions of the western US. Ecography 41: 910-921.

Paulson, A.K. S. Sanders, J. Kirschbaum, and D.M. Waller. 2016. Post-settlement ecological changes in the forests of the Great Lakes National Parks. Ecosphere 7(10). https://doi.org/10.1002/ecs2.1490.

Pernin, P. 1971. The great Peshtigo fire: an eyewitness account. Wisconsin Magazine of History 54: 246-272.

Pickett, S.T.A., and P.S. White. 1985. The ecology of natural disturbance and patch dynamics. Orlando: Academic Press. 
Pyne, S.J. 2001. Year of the fires: the story of the Great Fires of 1910. New York: Penguin Books.

Radeloff, V.C., D.J. Mladenoff, H.S. He, and M.S. Boyce. 1999. Forest landscape change in the northwestern Wisconsin pine barrens from pre-European settlement to the present. Canadian Journal of Forest Research 29: 1649-1659.

Rhemtulla, J.M., D.J. Mladenoff, and M.K. Clayton. 2009. Legacies of historical land use on regional forest composition and structure in Wisconsin, USA (mid-1800s-1930s-2000s). Ecological Applications 19: 1061-1078.

Roth, F. 1898. On the forestry conditions of northern Wisconsin. Madison: Wisconsin Geological and Natural History Survey, Bulletin No. 1, Economic Series No. 1.

Roth, F. 1905. Yearly report of the warden of the forest reserves. Report of the Michigan ForestryCommission for the Years 1903-1904, 21-41. Lansing, $\mathrm{MI}$.

Rummel, W. 2003. The Great Fire of 1881: how the thumb survived. Huron Daily Tribune. Bad Axe: Huron Publishing Company.

Safford, M.N., J. Weins, and G.D. Hayward. 2012. The growing importance of the past in managing ecosystems of the future. In Historical Environmental Variation in Conservation and Natural Resource Management, ed. J.A. Wiens, G.D. Hayward, H.D. Safford, and C.M. Giffen ISBN 9781444337921.

Sands, B.A., and M.D. Abrams. 2011. A 183-year history of fire and recent fire suppression impacts in select pine and oak forest stands of the Menominee Indian Reservation, Wisconsin. The American Midland Naturalist 166: 325-338.

Schulte, L.A., and D.J. Mladenoff. 2005. Severe wind and fire regimes in northern forests: historical variability at the regional scale. Ecology 86 : 431-445.

Schulte, L.A., D.J. Mladenoff, T.R. Crow, L.C. Merrick, and D.T. Cleland. 2007. Homogenization of northern U.S. Great Lakes forest due to land use. Landscape Ecology 22: 1089-1103.

Sickley, T.A., D.J. Mladenoff, V.C. Radeloff, and K.L. Maines. 2001. A pre-European settlement vegetation database for Wisconsin. Forest Landscape Ecology Lab. Madison: University of Wisconsin. https://www.sco.wisc.edu/glo/ dist/docs/GLOUserGuide_v3.pdf. Accessed 19 Feb 2020.

SigmaPlot Version 12.0. 2010. Systat Software. San Jose, CA.

Speer, J.H. 2010. Fundamentals of tree-ring research. Tucson: University of Arizona Press.

Stearns, F.W. 1997. History of the Lake States forests: natural and human impacts. In Lake States Regional Forest Resources Assessment, ed. J.M. Vasievich and H.H. Webster, 35. USDA Forest Service GTR-NC-189. St. Paul, MN.

Steel, Z.L., H.D. Safford, and J.H. Viers. 2015. The fire frequency-severity relationship and the legacy of fire suppression in California forests. Ecosphere 6: 8. https://doi.org/10.1890/ES14-00224.1.

Steen-Adams, M., N. Langston, and D.J. Mladenoff. 2007. White pine in the northern forests: an ecological and management history of white pine on the Bad River Reservation Wisconsin. Environmental History 12 614-648.

Stephens, S., J.D. Mclver, R.E. Boerner, C. Fettig, J.B. Fontaine, B.R. Hartsough, P.L. Kennedy, and D.W. Schwilk. 2012. Effects of forest fuel-reduction treatments in the United States. Bioscience 63: 549-560.

Stewart, L.O. 1935. Public land surveys - history, instructions, methods. Ames: Collegiate Press.

Stimson, J.V. 1910. Forestry. The Lumber World 10 (6): 18-19.

Sutheimer, C.M., J. Meunier, S.C. Hotchkiss, E. Rebitzke, and V.C. Radeloff. 2021. Historical fire regimes of North American hemiboreal peatlands. Forest Ecology and Management 498: 119561. https://doi.org/10.1016/j.foreco. 2021.119561.

Swetnam, T.W., and C.H. Baisan. 1996. Historical fire regime patterns in the southwestern United States since AD 1700. In Fire effects in southwestern forests, ed. C.D. Allen, 11-32. Fort Collins: Proceedings of the Second La Mesa Fire Symposium. General Technical Report RM-GTR-286. USDA Forest Service.

Thompson, J.R., D.N. Carpenter, C.V. Cogbill, and D.R. Foster. 2013. Four centuries of change in northeastern United States forest. PLOS ONE 8 (9): e72540.

Turner, M.G., R.H. Gardner, V.H. Dale, and R.V. O'Neill. 1989. Predicting the spread of disturbance across heterogeneous landscapes. Oikos 55 $121-129$.
U.S. Fish and Wildlife Service. 2004. Necedah National Wildlife Refuge Comprehensive Conservation Plan. Washington, D.C: U.S. Fish and Wildlife Service Available online at http://www.fws.gov/midwest/planning/Necedah/ ccp/FinalCCP.pdf.

Weaver, J.E., and F.E. Clements. 1929. Plant ecology. McGraw-Hill: New York. Wells, R.W. 1968. Fire at Peshtigo. Englewood Cliffs: Prentice-Hall.

White, M.A., and G.E. Host. 2008. Forest disturbance frequency and patch structure from pre-European settlement to present in the Mixed Forest Province of Minnesota, USA. Canadian Journal of Forest Research 38 : 2212-2226.

White, M.A., and D.J. Mladenoff. 1994. Old-growth forest landscape transitions from pre-European settlement to present. Landscape Ecology 9: $191-205$.

Whitney, G.G. 1987. An ecological history of the Great Lakes forests of Michigan. Journal of Ecology 75: 667-684.

Whitney, G.G. 1990. The history and status of the hemlock-hardwood forest of the Allegheny Plateau. Journal of Ecology 78: 443-458.

Williams, D.E. 1955. Fire hazard resulting from jack pine slash. Forest Research Division Technical Note No. 22. Department of Northern Affairs and National Resources Forestry Branch. Ontario, Canada.

Williams, M. 1989. Americans and their forests: a historical geography, 599. Cambridge: Cambridge University Press.

Wisconsin Department of Natural Resources. 2015. The ecological landscapes of Wisconsin: An assessment of ecological resources and a guide to planning sustainable management. Madison: Wisconsin Department of Natural Resources, PUB-SS-1131.

Wisconsin Historical Society. Forest Fires in Wisconsin. https://www.wisconsinh istory.org/Records/Article/CS1699. Accessed September 2021.

Wright, C.S., A.M. Evans, S. Grove, and K.A. Haubensak. 2019. Pine age and burn season influence fuelbed properties, and charcoal formation when burning hand piles. Forest Ecology and Management 439: 146-158.

Wright, H.E., Jr., and M.L. Heinselman. 2014. The ecological role of fire in natural conifer forest of western and northern North America - introduction. Fire Ecology 10: 4-13.

Zon, R., and R.N. Cunningham. 1931. Logging slash and forest protection, 109. Lake States Forest Experimental Station, Research Bulletin. Madison: University of Wisconsin.

\section{Publisher's Note}

Springer Nature remains neutral with regard to jurisdictional claims in published maps and institutional affiliations.

\section{Submit your manuscript to a SpringerOpen ${ }^{\circ}$ journal and benefit from:}

- Convenient online submission

- Rigorous peer review

- Open access: articles freely available online

- High visibility within the field

- Retaining the copyright to your article

Submit your next manuscript at springeropen.com 